\title{
Design and synthesis of spirocyclic ligands of glucorticoid receptors
}

\author{
Eduard Badarau $^{\mathrm{a}, \mathrm{b}}$, Frédéric Robert ${ }^{\mathrm{c}}$, Stéphane Massip ${ }^{\mathrm{a}}$,Florian Jakob ${ }^{\mathrm{d}}$, Simon Lucas ${ }^{\mathrm{d}}$, \\ Sven Frormann ${ }^{\mathrm{d}}$ and Léon Ghosez ${ }^{\mathrm{a}} *$ \\ ${ }^{a}$ Univ. Bordeaux, European Institute of Chemistry and Biology (IECB), 2 Rue Robert Escarpit, 33607 Pessac, \\ France \\ ${ }^{b}$ Present address: Univ. Bordeaux, Institute of Chemistry \& Biology of Membranes \& Nano-objects (CBMN), \\ Allée Geoffroy Saint Hilaire, Bât B14, 33600 Pessac, France \\ ${ }^{c}$ Univ. Bordeaux, Institute of Molecular Sciences (ISM), CNRS UMR 5255, F-33400 Talence, France. \\ ${ }^{d}$ Grunenthal GmbH, Zieglerstr. 6, 52078 Aachen, Germany
}

\begin{abstract}
Spirocyclic indazoles were designed as potential ligands for the glucocorticoid receptors (GRs). A short and efficient synthetic sequence was developed allowing the preparation of pure diastereomeric spirocyclic analogs of fluorocortivazol. Our studies also revealed a new application of Burgess reagent leading to a ring expansion. The structures and conformations of several key intermediates and products were confirmed by single crystal X-ray diffraction analysis. Conformational assignments were also supported by DFT calculations. As a proof of concept we tested the affinity of diastereomeric compounds $\mathbf{1 3 b}$ and $\mathbf{1 4 b}$ for the GRs. Rewardingly, it was found that $14 \boldsymbol{b}$ showed a promising IC $C_{50}$ of $27 \mathrm{nM}$.
\end{abstract}

Keywords: Spirocycles, Benzopyrazole, Glucocorticoids, Burgess reagent

\section{Introduction}

Glucocorticoids (GCs) belong to the most efficient agents currently used for the treatment of allergic and inflammatory diseases. Prednisolone, dexamethasone and fluorocortivazol are notable examples of this class of drugs. Unfortunately their immunosuppressive effects are often accompanied by side effects such as muscle atrophy, ${ }^{1}$ steroid-induced osteoporosis, ${ }^{2}$ diabetes mellitus ${ }^{3}$ and hypertension. ${ }^{4}$

We have recently initiated a research program aiming at developing new potential ligands for the glucocorticoid receptors (GRs). We started from the simplified analogues of fluorocortivazol (MK, Scheme 1) uncovered by Ali and coll. ${ }^{5}$ which were developed as promising selective glucocorticoid receptor modulators (SEGRMs). ${ }^{6}$ As originally demonstrated, the steroidal rings $\mathrm{C}$ and $\mathrm{D}$ of fluorocortivazol could be successfully replaced by lipophilic substituents at $\mathrm{C}_{11}$. The introduction of various side-chains R carrying aryl substituents led to the discovery of fluorocortivazol analogs with an $\mathrm{IC}_{50}$ in the low $\mathrm{nM}$ range for hGRs.

Starting from the MK ligand, we decided to explore a spirocyclic pattern resulting from disconnecting $\mathrm{C}_{7}$ from $\mathrm{C}_{7 \mathrm{a}}$ and reconnecting $\mathrm{C}_{7}$ with the methyl group at $\mathrm{C}_{4 a}$ (Scheme 1, target structures). The replacement of steroidal fused-rings by a spiranic structure should increase the conformational freedom of the B-D rings with less entropy loss than with a simple alkyl tether. Several low-energy conformations could be available in solution thus offering more possibilities for a better interaction with the receptor.

* Corresponding author. Tel.: +33 (5) 400030 38; e-mail: 1.ghosez@ iecb.u-bordeaux.fr 


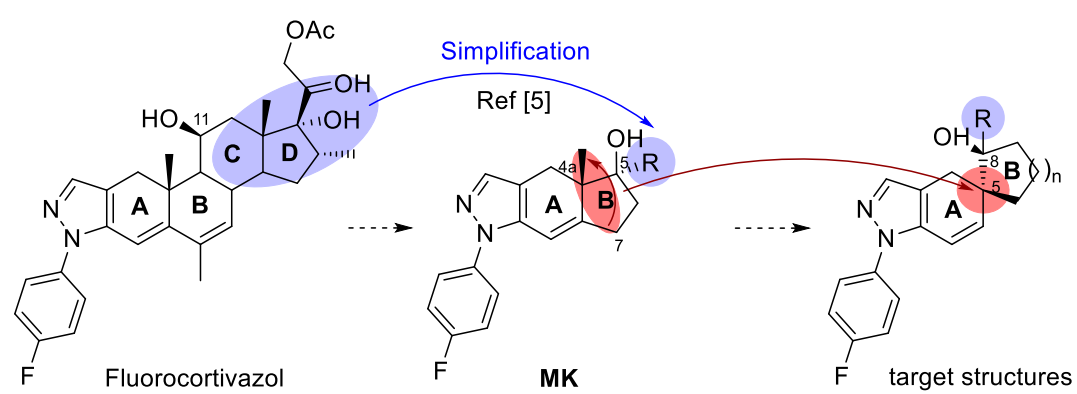

Scheme 1. Design of new potential spiro-corticoids

\section{Synthesis}

This initial study was intended to validate the synthetic access to this type of compounds and not to fully explore the structure-activity relationships generated by variation of substituents (R), or the size (n) of the spirocyclic ring (Scheme 1). From this perspective, it did not require an access to enantiopure compounds. The stereochemical challenge was thus limited to the generation of pure diastereomers. Since the conformational flexibility should increase with the size of the spirocyclic ring, we decided to prepare representative alcohols of the homologous 5- and 6-membered B-rings. These should be easily obtained by addition of an organometallic reagent to the corresponding 5- and 6-membered ring ketone (Scheme 2).

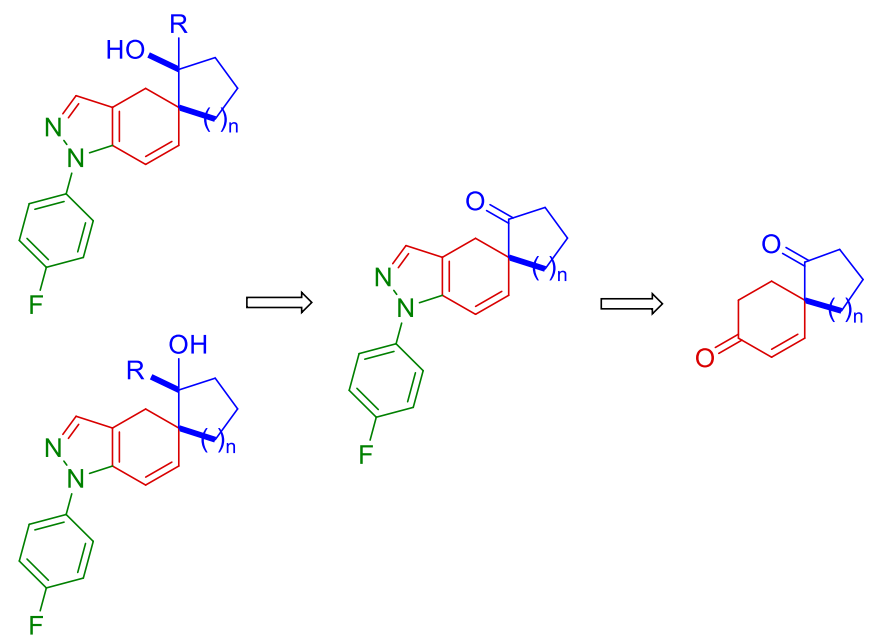

Scheme 2. Retrosynthetic analysis

\subsection{Synthesis of the spirodiketone intermediates}

The preparation of the known spirodiketones 5a-b was inspired by literature precedents (Scheme 3). As already pointed out by Eaton and $\mathrm{Jobe}^{7}$ the formylation of cyclopentanone was best effected with ethylformate in the presence of potassium hydride. For the higher homologs $(n=2)$ we found that the reaction proceeded smoothly in the presence of the cheaper but weaker base, sodium hydride. Compounds 1a-b were used without purification in the Michael addition to methyl vinyl ketone in the presence of catalytic amounts of DBU and triethylamine. ${ }^{8}$ This classical sequence of reactions allowed the preparation of multigram quantities of $\mathbf{2 a - b}$ in good overall yields.

Surprisingly the spiroannulation step turned out to be more difficult than anticipated (Scheme 3). The methanesulfonic acid-catalyzed spiroannulation described by Eaton and Job ${ }^{7}$ for the preparation of 5a-b did not work well in our hands giving low yields of the desired spirodiketones. Variations of some reaction parameters (concentration, temperature, use of PTSA or triflic acid) were not successful: these 
reactions gave complex mixtures or starting material was recovered. Eventually, an annulation product 3 was isolated in $60 \%$ yield from the treatment of $\mathbf{2 b}(n=2)$ with 0.5 eq. of $\mathrm{MsOH}$ in benzene followed by azeotropic distillation of water. An X-ray diffraction analysis of a crystal of the corresponding 2,4dinitrophenylhydrazone $\mathbf{4}$ confirmed the structure of $\mathbf{3}$. Compound $\mathbf{3}$ was the result of an acid-catalyzed deformylation of the non-enolizable ketone $\mathbf{2 b}(\mathrm{n}=2)$ followed by an intramolecular aldol reaction. Both acidic and basic conditions have indeed been used for the decarbonylation of non-enolizable $\alpha$ formylated ketones. ${ }^{9}$

This competitive reaction could be avoided by applying a variation of the conditions described earlier by de Groot et al. for related spiroannulation reactions. ${ }^{10}$ The spiroannulation of $\mathbf{2 a - b}$ was thus performed in the presence of a 1:1 mixture of morpholine and acetic acid in DMSO at room temperature, and conducted to the

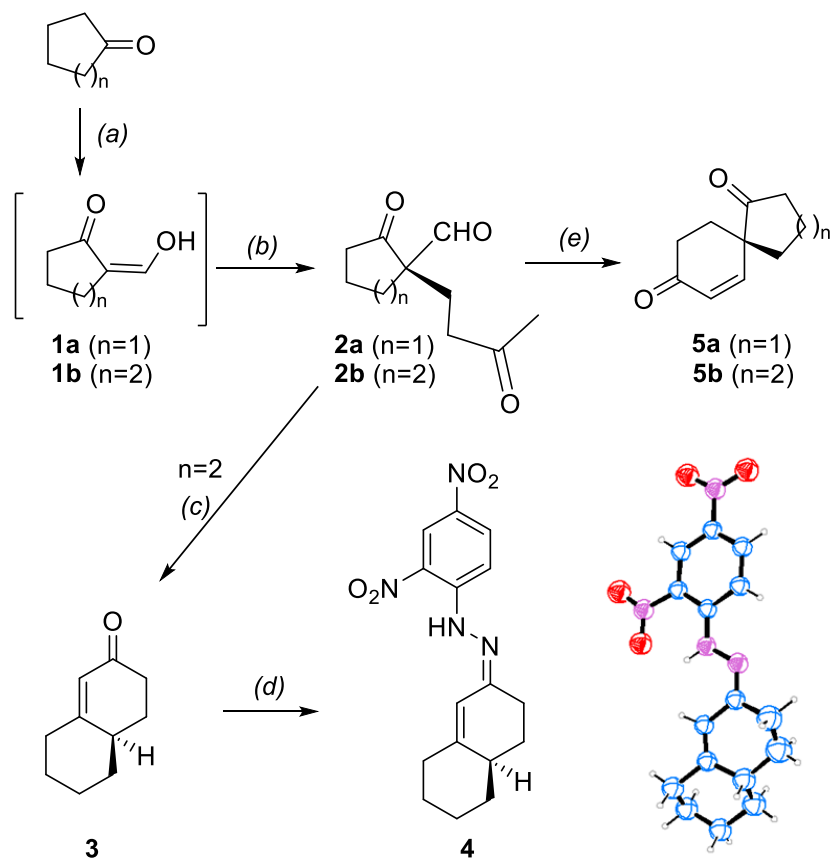

Scheme 3. Synthesis of the spirodiketones 5. (a) for $n=1: \mathrm{KH}$, HCOOEt in $\mathrm{Et}_{2} \mathrm{O}, 1 \mathrm{~h}, 0^{\circ} \mathrm{C}$ to $\mathrm{rt}$; for $\mathrm{n}=2$ : $\mathrm{NaH}$, $\mathrm{HCOOEt}$ in $\mathrm{Et}_{2} \mathrm{O}, 48 \mathrm{~h}$, rt ; (b) for $\mathrm{n}=1$ : methyl vinyl ketone, $\mathrm{KOH} / 2 \mathrm{~h}$, rt, 55\%; for $\mathrm{n}=2$ : methyl vinyl ketone, DBU, TEA / THF, 12 h, rt, 49\%; (c) MsOH (0.5 eq.) / $\mathrm{PhCH}_{3}, 12 \mathrm{~h}$, reflux, 60\%; (d) dinitrophenylhydrazine, $\mathrm{H}_{2} \mathrm{SO}_{4}$ / EtOH, 30 min, rt; (e) morpholine : $\mathrm{AcOH}(1: 1) / \mathrm{DMSO}, 24 \mathrm{~h}, \mathrm{rt},(\mathrm{n}=1: 34 \%, \mathrm{n}=2: 73 \%)$.

\subsection{Construction of the pyrazole ring}

The construction of the pyrazole ring first required the protection of the saturated ketone. Inspection of molecular models had revealed that the saturated ketone was fairly congested which raised the problem of chemoselectivity of the ketalization reaction. The desired selective ketalization of the saturated ketone was observed upon treatment of $\mathbf{5 b}(n=2)$ with 1 eq. PTSA in the presence of molecular sieves at room temperature. The lower homolog $\mathbf{5 a}(\mathrm{n}=1)$ behaved differently: treatment of 5a with 1 equivalent PTSA at room temperature yielded compound 7. The structure of $\mathbf{7}$ was confirmed by X-ray diffraction analysis of monocrystals of diphenylhydrazone $\mathbf{8}$. The formation of $\mathbf{7}$ could be explained by an acid-catalyzed cleavage of the tetrahedral intermediate generated by addition of ethylene glycol to the carbonyl group of 5 a (Scheme 4). 


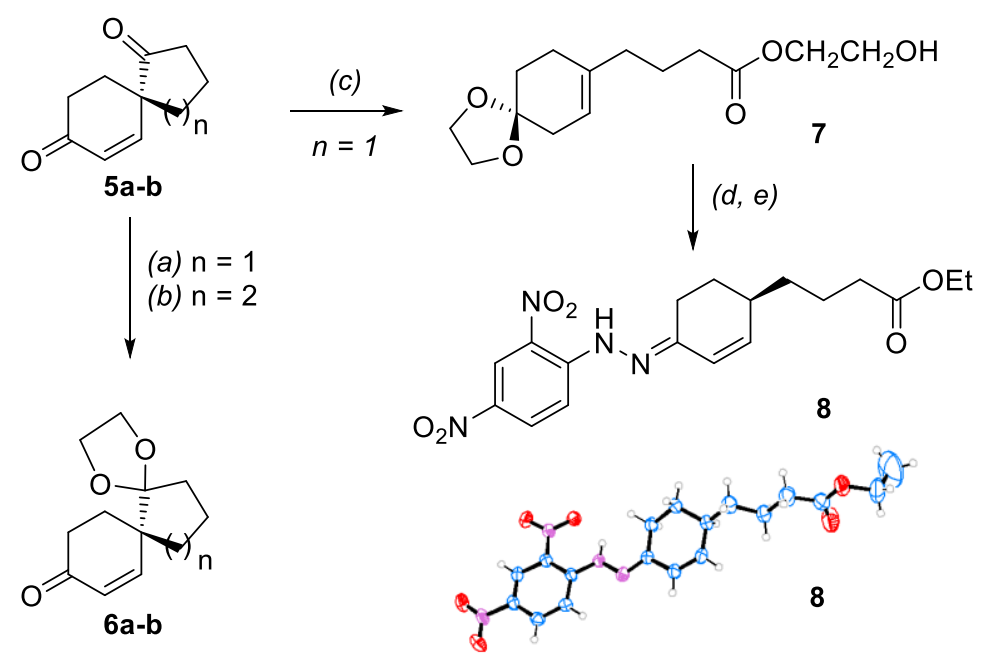

Scheme 4. Selective ketalization of spiranediones 5. (a) ethylene glycol, CSA (0.1 eq.), m.s. $4 \AA$ / 40 min, rt, 69\%; (b) ethylene glycol, PTSA (1 eq.), m.s. $4 \AA$ / 1 h, rt, 72\%; (c) ethylene glycol, PTSA (1 eq.), m.s. $4 \AA$ / 40 min, rt, 63\%; (d) $\mathrm{NaH}, \mathrm{HCOOEt}, \mathrm{PhCH}_{3} / 1$ h, $0^{\circ} \mathrm{C}$ to rt; (e) 2,4-dinitrophenyl-hydrazine, $\mathrm{H}_{2} \mathrm{SO}_{4}$ in EtOH / $\mathrm{H}_{2} \mathrm{O}$.

A DFT study of the fragmentation reactions in the 5- and 6-membered spirocycles showed that, despite similar energy barriers for the fragmentation in both series, the reaction was exothermic only in the case of the 5-membered ring (Scheme 5). Eventually we were able to obtain the desired ketal 6a in $69 \%$ yields after treatment of $\mathbf{5 a}$ with 0.1 eq. of CSA for $40 \mathrm{~min}$.

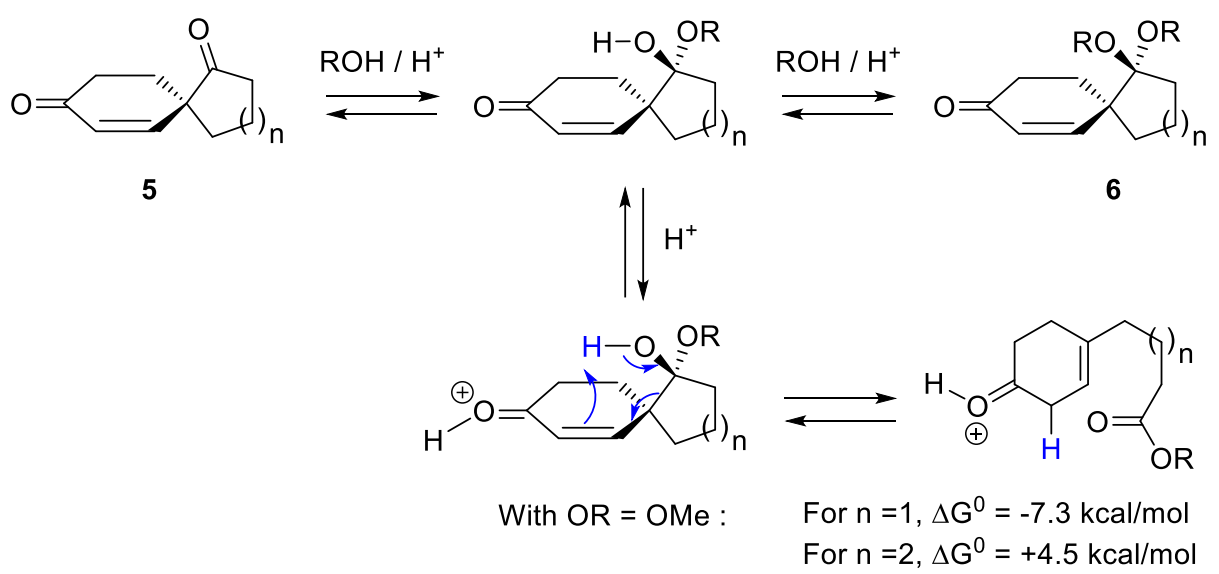

Scheme 5. DFT calculations at the M06-2X/6-31+G(d,p) level.

The protected ketones $\mathbf{6 a - b}$ were first formylated then reacted with $p$-fluorophenyl hydrazine to yield the tricyclic pyrazoles 9a-b in 61\% and 73\% respectively (Scheme 6). Hydrolysis of 9a-b yielded ketones 10a-b (66\% and $71 \%$, respectively). 


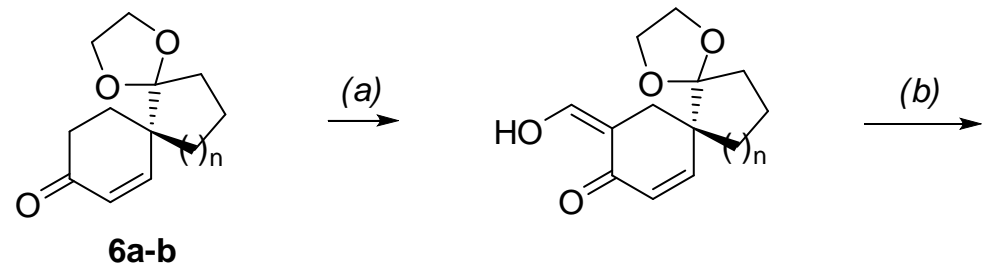
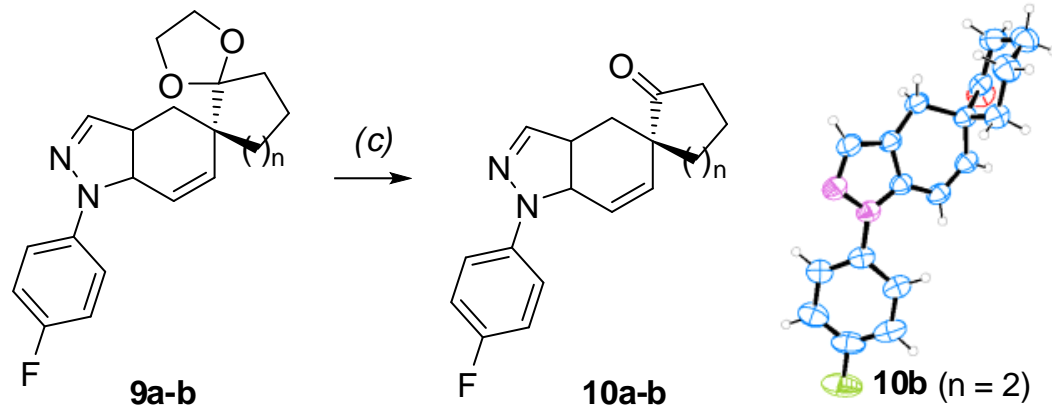

Scheme 6: Construction of the pyrazole ring. (a) : NaH, HCOOEt, MeOH / toluene / $48 \mathrm{~h}$, rt; (b) 4-F-Ph-NHNH $\mathrm{AcONa} / \mathrm{AcOH} / 24 \mathrm{~h}$, rt, (over two steps, 9a: 61\%, 9b: 73\%); (c) $\mathrm{HCl} / \mathrm{THF} / 1.5 \mathrm{~h}, 65^{\circ} \mathrm{C},(\mathbf{1 0 a}: 66 \%, \mathbf{1 0 b}$ $71 \%)$.

The structure and conformation of the six-membered ketone $\mathbf{1 0 b}(\mathrm{n}=2)$ was established by X-ray diffraction analysis. A DFT conformational analysis (M06-2X/6-311+G(2d,p) level in chloroform) was also performed on this derivative (Scheme 7). They revealed that the conformer observed in the crystal was also preferred in chloroform (A, Scheme 7) although another chair conformation, quite similar in energy, of the cyclohexanone ring exists (B, Scheme 7). The full details of the conformational analyses can be found in the supplementary material.
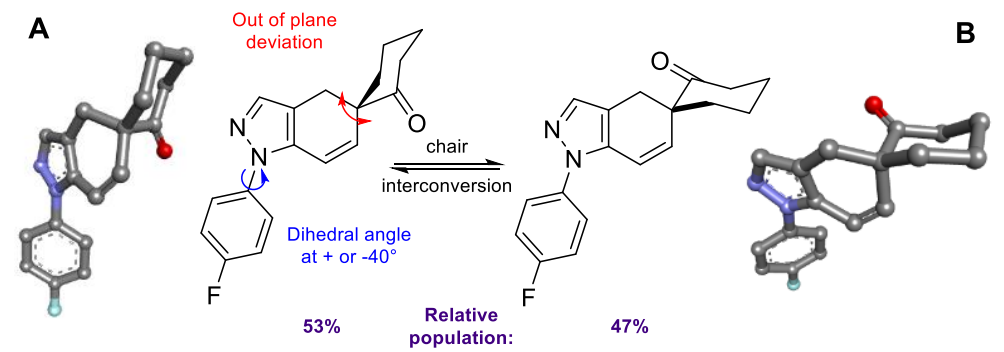

Scheme 7 : DFT conformational analysis of the 6-membered ketone $\mathbf{1 0 b}$

\subsection{Synthesis of the target alcohols}

The final step of the synthesis was the generation of the target alcohols from ketones 10a-b. Our studies were first conducted on the 6-membered ring ketone 10b. The stereochemical course of addition of metal hydrides, organolithium or Grignard reagents to cyclohexanones is known to be a complex process depending on many experimental parameters. In addition, the conformational analysis of each ketone had revealed the presence of several conformers of similar energy. However, as different diastereomeric alcohols could provide more informative biological data, mixtures of diastereoisomers were therefore acceptable as long as these could be separated and purified.

Reduction of the ketone 10b with DIBAL-H yielded a 1:3 mixture of secondary alcohols $\mathbf{1 1}$ and $\mathbf{1 2}$ in 90\% yield (Scheme 8). The evidence for the presence of the two isomers was provided by the splitting of ${ }^{1} \mathrm{H}-\mathrm{NMR}$ signals (especially those of the vinylic protons) in the crude reaction mixture. Axial and 
equatorial alcohols 11 and $\mathbf{1 2}$ were separated by preparative HPLC. Their structures, relative configurations and their conformations were confirmed by X-ray diffraction analyses (Figure 1).

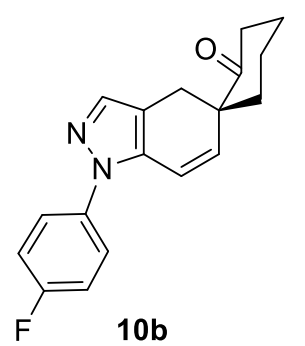

(a)
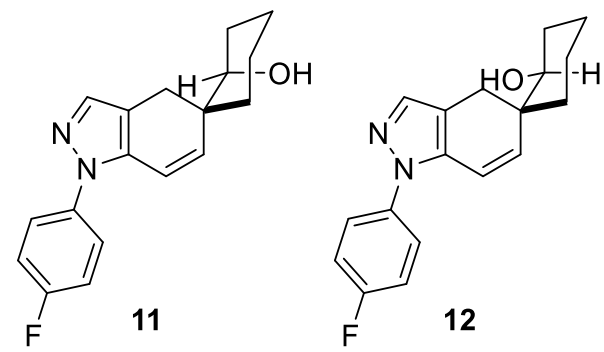

Scheme 8. (a) DIBAL-H, Toluene, $-78^{\circ} \mathrm{C}, 1 \mathrm{~h}, \mathbf{1 1}(22 \%)$ and $12(68 \%)$.
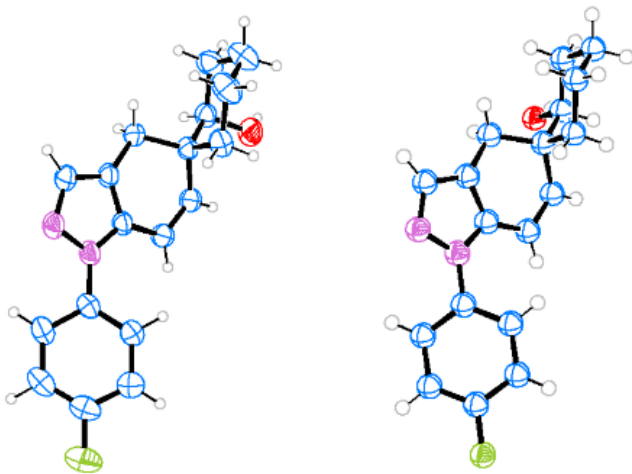

Figure 1. Crystal structures of secondary alcohols $\mathbf{1 1}$ and $\mathbf{1 2}$

As expected, addition of organolithium or Grignard reagent to ketone 10b generated a mixture of tertiary alcohols (Table 1). The structure of the major diastereoisomer $\mathbf{1 3}$ was revealed in the case of 13a, by X-rays diffraction analysis of crystals obtained in acetonitrile (Figure 2, 13a). Molecular modeling showed that the minor distereoisomer $\mathbf{1 4}$ would have another orientation of the spirocyclic ring, carrying the bulky substituent on the alcohol in the equatorial position (Figure 2, 13b). As the orientation of the alcohol moiety is different from one diasteroisomer to another, this should strongly influence the interaction the glucocorticoid receptors.

Table 1. Reaction of organometallics with ketone 10b

\begin{tabular}{llll}
\hline $\mathrm{R}$ & Conditions $^{\mathrm{a}, \mathrm{b}}$ & \multicolumn{2}{c}{ Diastereoisomers $^{\mathrm{c}}$} \\
\hline $\mathrm{H}$ & DIBAL-H & $\mathbf{1 1}(22 \%)$ & $\mathbf{1 2}(68 \%)$ \\
1-propynyl & 1-propynylMgBr & $\mathbf{1 3 a}(61 \%)$ & $\mathbf{1 4 a}(\mathrm{NI})$ \\
benzyl & benzylMgBr & $\mathbf{1 3 b}(81 \%)$ & $\mathbf{1 4 b}(13 \%)$ \\
2-Naphtyl & 2-naphtyl-Li & $\mathbf{1 3 c}(49 \%)$ & $\mathbf{1 4 c}(\mathrm{NI})$ \\
p-MeOPh & p-MeOPhMgBr & $\mathbf{1 3 d}(48 \%)^{\mathrm{d}}$ & $\mathbf{1 4 d}(\mathrm{NI})$
\end{tabular}

a reactions performed in THF; ${ }^{\mathrm{b}}$ not optimized; ${ }^{\mathrm{c}}$ yields of pure compounds after chromatography or/and recrystallization unless otherwise mentioned; ${ }^{d}$ conversion $(40 \%$ starting material was recovered); NI $=$ Not isolated. 

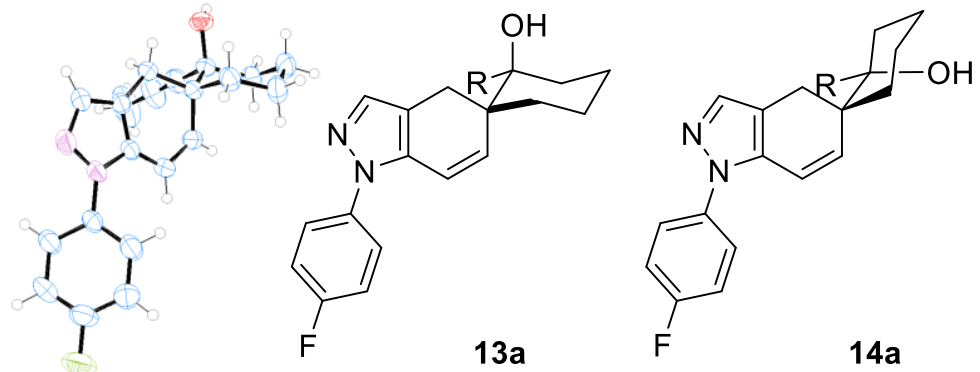

Figure 2. Structures of tertiary alcohols $13 \mathbf{a}$ and $14 \mathbf{a}(\mathrm{R}=1$-propynyl $)$

\subsection{An unprecedented behaviour of Burgess reagent}

We were also interested in the dehydrated derivatives starting from a mixture of $\mathbf{1 1}$ and $\mathbf{1 2}$. Unfortunately classical dehydration conditions $\left(\mathrm{Tf}_{2} \mathrm{O} /\right.$ toluene or pyridine, or $\mathrm{Ac}_{2} \mathrm{O} /$ pyridine $)$ yielded a complex mixture of products containing only traces of elimination product $\mathbf{1 5}$. As an alternative, we tested the Burgess reagent which has been successfully used for the syn-dehydration of alcohols. ${ }^{11}$ However, refluxing a mixture of alcohols $\mathbf{1 1}$ and $\mathbf{1 2}$ with 1.1 equiv. of methyl-N(triethylammoniumsulfonyl)-carbamate (Burgess reagent) in dry THF did not yield the expected elimination product 15 (Scheme 9, pathway A), but partially converted the starting material into a new product 16. A complete transformation of the starting material into $\mathbf{1 6}$ was observed in the presence of 2.2 equiv. of Burgess reagent (Scheme 9). The structure of this unexpected product 16 was unequivocally confirmed by X-rays diffraction analysis. Compound $\mathbf{1 6}$ thus resulted from a ring expansion of the cyclohexadiene B-ring. We first envisaged (Pathway B) involving an intramolecular abstraction of a hydrogen atom of the B-ring concerted with a nucleophilic attack of the activated alkene on the carbon carrying the leaving group (noted $a$ ). This would give a strained norcaradiene that would isomerize readily to the more stable cycloheptatriene $16 .{ }^{12}$ An alternative mechanism preferred by the referees would be a direct attack of the fairly nucleophilic and properly oriented double bond (pathway C) to give a stabilized tetracyclic cation that would undergo a base-catalyzed rearrangement to $\mathbf{1 6 .}$

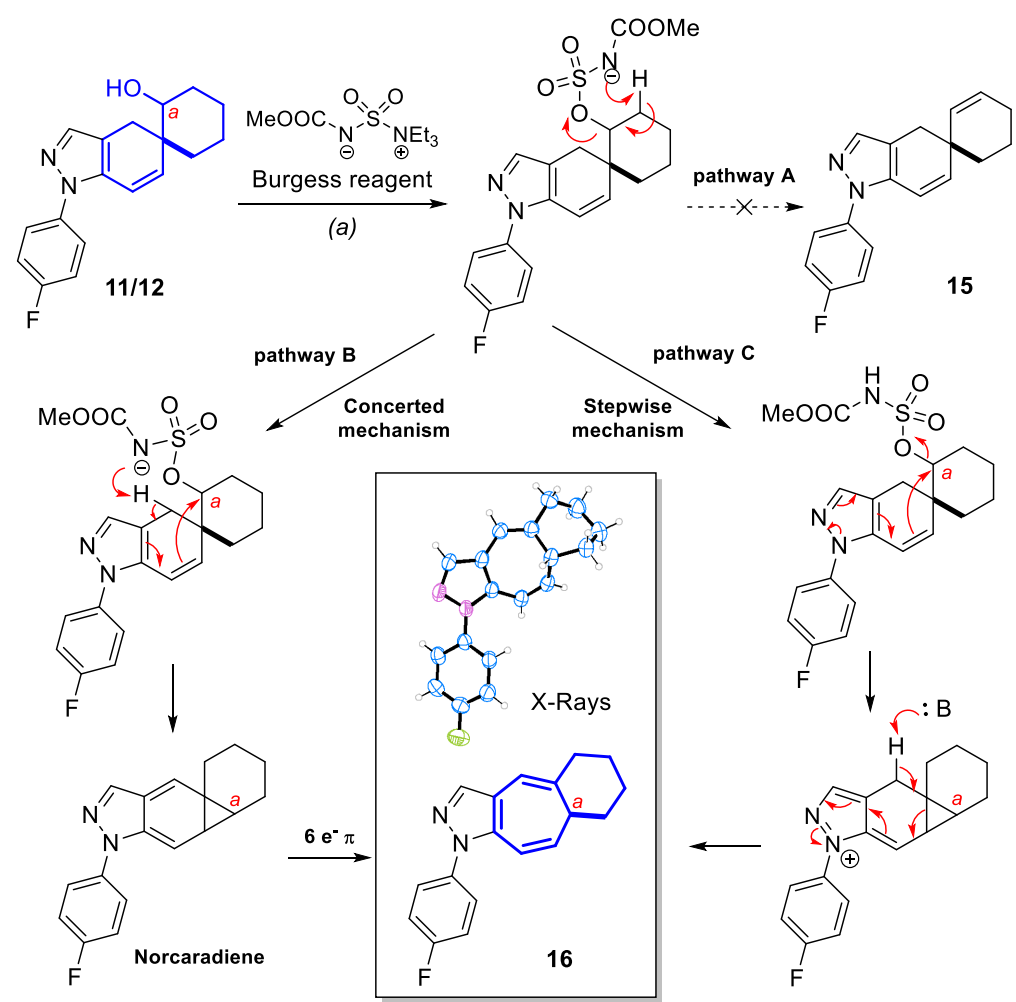

Scheme 9. (a). Burgess reagent / THF, reflux, $1 \mathrm{~h}(87 \%)$. 
We applied the same experimental conditions to the saturated analogue 17 (Scheme 10). The reaction did not yield a ring expansion product nor an elimination product: the sulfonylated was recovered unchanged after $3 \mathrm{~h}$ at $80^{\circ} \mathrm{C}$.

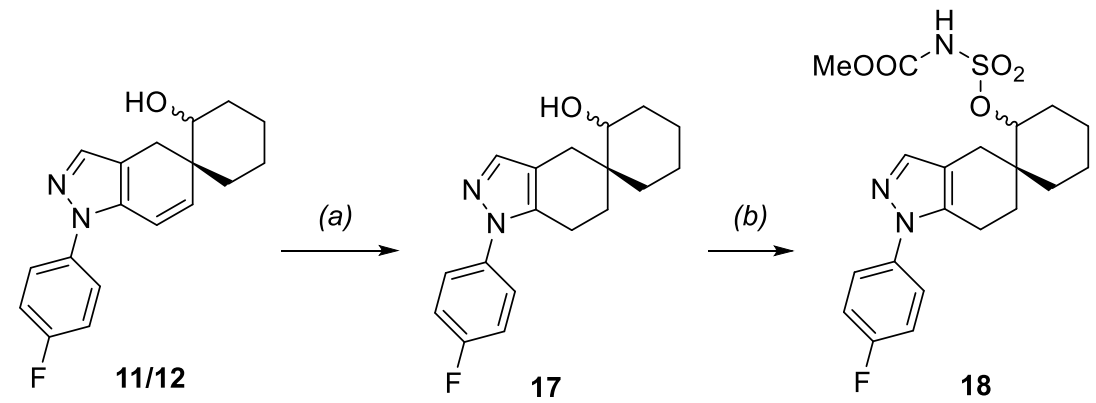

Scheme 10. (a) $\mathrm{H}_{2}, \mathrm{Pd} / \mathrm{C}, \mathrm{HCl}(1 \mathrm{~N}) / \mathrm{EtOH}$; (b) Burgess reagent (2.2 eq.) / THF, reflux, $3 \mathrm{~h}$ (16\% over two steps).

As far as we can tell this ring expansion reaction represents an unprecedented application of Burgess reagent.

Eventually we managed to obtain the elimination product 15 using the Shapiro reaction. The hydrazone 19 was obtained in good yield $(77 \%)$ by treatment of the ketone $\mathbf{1 0 b}$ with tosylhydrazine in ethanol. Subsequent addition of $n$-BuLi ( 2 eq.) at low temperature delivered a rather low yield of the olefin 15 along with unidentified degradation products (Scheme 11).
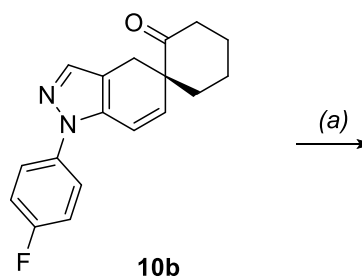

$10 \mathrm{~b}$
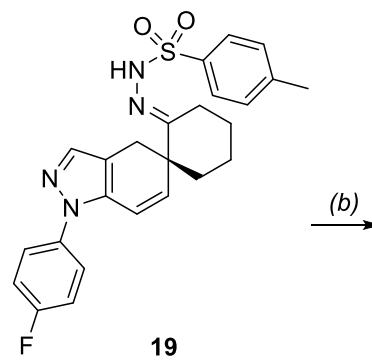

Scheme 11. (a) p-Toluenesulfonyl hydrazide, $\mathrm{HCl} / \mathrm{EtOH}, 12 \mathrm{~h}$, r.t. (77\%); (b) $n$-BuLi / THF, $3 \mathrm{~h}, 0^{\circ} \mathrm{C}$ to r.t. $(34 \%)$.

\section{Conclusions}

Spirocyclic indazoles were designed as potential ligands for the glucocorticoid receptors. Although the synthetic route to these compounds originally appeared as straightforward, in practice the construction of the homologous in 5- and 6-membered spiranic ring systems required specific sequences for each member of the homologous series as a consequence of very different reactivity patterns. Eventually, we were able to establish practical synthetic routes for each member of the homologous series. The last step leading to the alcohols yielded two diastereomers. As examples, we separated both diastereoisomers 11 and 12 and also 13b and 14b. The conformations of representative final products and key intermediates were also studied by DFT calculations and confirmed by X-rays diffraction analyses. These synthetic studies offer chemists an easy access to a wide variety of structural analogs of this new class of spirocycles. They can be easily modulated to conduct to new glucocorticoids. In order to test the validity of our design we tested both diastereoisomers $\mathbf{1 3 b}$ and $\mathbf{1 4 b}$. If the isomer $\mathbf{1 3 b}$ is devoid of affinity for the GRs, having an $\mathrm{IC}_{50}$ of $5.7 \mu \mathrm{M}$, the corresponding diastereoisomer 14b has a promising $\mathrm{IC}_{50}$ of $27 \mathrm{nM}$. The completely different binding pattern of these isomers could result from the different position of the hydroxyl moiety, expected to mimic the initial $\mathrm{C}_{11}$ alcohol of 
fluorocortivazol. More examples in this series are necessary in order to define the SAR for this class of derivatives. This will be discussed in a forthcoming publication in a medicinal chemistry journal.

In the course of our synthetic studies, we also discovered an unprecedented application of Burgess reagent. Instead of generating an olefin by an intramolecular syn-elimination, the product resulting from the treatment of spirocyclic alcohols $\mathbf{1 1}$ and $\mathbf{1 2}$ with Burgess reagent led to the expansion of the cyclohexadiene ring. Our future plan is to examine whether this observation could be generalized to other systems containing an allylic hydrogen atom.

We believe that these preliminary synthetic studies open a new window for the discovery of new potent and selective glucocorticoid ligands.

\section{Experimental}

\subsection{General experimental}

The infrared (IR) spectra were recorded on a Bruker IRFT IFS 55 spectrometer on zinc selenide plates, unless stated otherwise.

${ }^{1} \mathrm{H}-\mathrm{NMR}$ and ${ }^{13} \mathrm{C}-\mathrm{NMR}$ were recorded with Bruker Avance II 300 (at $300.18 \mathrm{MHz}$ and $75.48 \mathrm{MHz}$, respectively) in $\mathrm{CDCl}_{3}-d 1$ and DMSO- $d 6$, using tetramethylsilane (TMS) as an internal standard. Chemical shifts are reported in parts per million (ppm) and the coupling constants are reported in units of Hertz [Hz]. Multiplicities were abbreviated as follows: singlet (s), doublet (d), triplet (t), quartet (q).

Low resolution mass spectra (MS) / High resolution mass spectra (HRMS) were recorded with a ThermoElectron LCQ Advantage and a ThermoElectron Exactive spectrometer, respectively.

Melting points were recorded using a Buchi B-540 apparatus and are uncorrected.

Flash chromatography was performed on Merck 40-70 nM (230-400 mesh) silica gel under air pressure. Thinlayer chromatography (TLC) was carried out on Merck silica gel 60 F254 precoated plates. Visualization was made with ultraviolet light $(\lambda=254 / 365 \mathrm{~nm})$ or using an aqueous potassium permanganate staining solution.

\subsection{Experimental details and characterization data}

\subsubsection{2-Oxo-1-(3-oxobutyl)cyclopentanecarb-aldehyde (2a).}

To a stirred suspension of $\mathrm{KH}(2.58 \mathrm{~g}, 30 \% \mathrm{w} / \mathrm{w}$ in oil, $19.39 \mathrm{mmol})$ in anhydrous $\mathrm{Et}_{2} \mathrm{O}(10 \mathrm{ml})$ was added dropwise a solution of cyclopentanone $(1 \mathrm{~g}, 11.89 \mathrm{mmol})$ and ethyl formate $(1.07 \mathrm{ml}, 13.32 \mathrm{mmol})$ in anhydrous $\mathrm{Et}_{2} \mathrm{O}(5 \mathrm{ml})$ at $-5^{\circ} \mathrm{C}$ for $15 \mathrm{~min}$ under argon atmosphere. The reaction mixture was stirred for additional $30 \mathrm{~min}$ and poured in ice/water $(25 \mathrm{ml})$. The aqueous layer was separated and washed with $\mathrm{Et}_{2} \mathrm{O}(10 \mathrm{ml} \times 2)$. The organic phase was discarded and aqueous phase was acidified with $\mathrm{NaH}_{2} \mathrm{PO}_{4}(1 \mathrm{~g})$ and concentrated $\mathrm{HCl}(3 \mathrm{ml}, \mathrm{pH}=1-2)$. The aqueous phase was extracted with $\mathrm{Et}_{2} \mathrm{O}(50 \mathrm{ml} \times 8)$. The combined organic phase was washed with saturated aqueous $\mathrm{NH}_{4} \mathrm{Cl}$ solution $(25 \mathrm{ml})$, dried over $\mathrm{Na}_{2} \mathrm{SO}_{4}$ and evaporated under vacuum to give a pale brown residue. The resulting residue was triturated with $\mathrm{n}$-pentane $(25 \mathrm{ml} \times 6)$ to give (E/Z)-2-(hydroxymethylene)cyclopentanone $1 \mathrm{a}$ as a white solid. The crude product $1 \mathrm{a}(8 \mathrm{~g}, 71.30 \mathrm{mmol})$ was dissolved in methyl vinyl ketone $(14.5 \mathrm{ml})$ and powdered $\mathrm{KOH}(181 \mathrm{mg}, 3.23 \mathrm{mmol})$ was added and the reaction mixture was stirred at room temperature for $2 \mathrm{~h}$. After the reaction was complete methyl vinyl ketone was evaporated under vacuum. The residue was dissolved in DCM $(100 \mathrm{ml})$ and washed with $1 \mathrm{M}$ aqueous solution of $\mathrm{NaH}_{2} \mathrm{PO}_{4}(30 \mathrm{ml} \times 2)$ followed by brine wash $(20 \mathrm{ml})$. The organic phase was dried over $\mathrm{Na}_{2} \mathrm{SO}_{4}$ and evaporated under vacuum to give the adduct 2a (12.2 g, 55\% over 2 steps, brown oil). This compound was used as such without purification for the next step. $\mathrm{C}_{10} \mathrm{H}_{14} \mathrm{O}_{3}$; brown oil; yield: $55 \% ; \mathrm{M}=182.22 \mathrm{~g} / \mathrm{mol}$; IR $\left(\mathrm{KBr}, \mathrm{cm}^{-1}\right): 2959,1713 .{ }^{1} \mathrm{H} \mathrm{NMR}$ (400 MHz; $\left.\mathrm{CDCl}_{3}\right)$ : 1.64-1.66 (m, 1H), 1.74-1.89 (m, 3H), 1.99-2.10 (m, 5H), 2.14-2.19 (m, 2H), 2.26-2.37 (m, 2H), 9.25 (s, 1H).

\subsubsection{2-oxo-1-(3-oxobutyl)cyclohexanecarb-aldehyde (2b)}

Sodium hydride (60\% dispersion in mineral oil, $11.4 \mathrm{~g}$ ) was added under nitrogen to dry diethyl ether (250 ml). Subsequently, ethyl formate ( $12.7 \mathrm{~g}, 13.8 \mathrm{ml}, 1.2 \mathrm{eq}$.$) and then cyclohexanone (12 \mathrm{~g}, 12.6 \mathrm{ml}, 1 \mathrm{eq}$.) were added and the mixture was stirred for $48 \mathrm{~h}$ at room temperature. The orange mixture was slowly poured on ice-cold water $(200 \mathrm{ml})$, the aqueous layer separated and washed with diethyl ether $(2 \times 200 \mathrm{ml})$ before being acidified with hydrogen chloride (aq. soln., $6 \mathrm{~N})$. The organic materials were extracted with diethyl ether $(3 \times 150 \mathrm{ml})$, the combined organic layers were dried over magnesium sulfate and the solvent was evaporated to conduct to the 
desired $\alpha$-formylated cyclohexanone $\mathbf{1 b}$ as a light-yellow liquid subsequently used without further purification. The crude compound $\mathbf{1 b}(6.42 \mathrm{~g}, 1$ eq. $)$ was dissolved in THF $(50 \mathrm{ml})$, then DBU $(0.06 \mathrm{ml}, 0.05$ eq. $)$, TEA $(0.06$ $\mathrm{ml}, 0.05$ eq.) and methyl acrylate $(1 \mathrm{ml}, 1.5$ eq.) were consecutively added to the mixture and stirred for $24 \mathrm{~h}$ at room temperature under inert atmosphere. After the complete consumption of the starting material, the solvent was evaporated, the residue diluted with DCM $(200 \mathrm{ml})$ and washed with ammonium chloride (sat. soln., 2 x 100 $\mathrm{ml}$ ) and sodium chloride (sat. soln., $1 \times 100 \mathrm{ml}$ ). The organic solvent was dried over magnesium sulfate and evaporated under vacuum. The crude product was purified by flash-chromatography (eluent: $\mathrm{PE} / \mathrm{EtOAc} 7 / 3$ ) to give the desired addition derivative $\mathbf{2 b}$ as a colorless oil $(10 \mathrm{~g}) . \mathrm{C}_{11} \mathrm{H}_{16} \mathrm{O}_{3}$; colorless oil; yield: $49 \% ; \mathrm{M}=196.24 \mathrm{~g}$ / mol; IR $(\mathrm{ZnSe}) v=2940,1715,1450,1367,1169 \mathrm{~cm}^{-1} ;{ }^{1} \mathrm{H}$ NMR $\left(300 \mathrm{MHz}, \mathrm{CDCl}_{3}\right) \delta 1.55-2.46(\mathrm{~m}, 15 \mathrm{H}) ;{ }^{13} \mathrm{C}$ NMR (75 MHz, CDCl $) \delta 21.4\left(\mathrm{CH}_{2}\right), 25.1\left(\mathrm{CH}_{2}\right), 26.7\left(\mathrm{CH}_{2}\right), 30.0\left(\mathrm{CH}_{3}\right), 32.9\left(\mathrm{CH}_{2}\right), 38.2\left(\mathrm{CH}_{2}\right), 40.7\left(\mathrm{CH}_{2}\right)$, 64.0 $\left(\mathrm{C}_{\mathrm{q}}\right), 201.2(\mathrm{CHO}), 207.6\left(\mathrm{C}_{\mathrm{q}}\right), 210.2\left(\mathrm{C}_{\mathrm{q}}\right)$.

\subsubsection{4,4a,5,6,7,8-hexahydro-3H-naphthalen-2- one (3)}

A solution of the previously obtained Michael adduct $\mathbf{2 b}(1.3 \mathrm{~g}, 6.62 \mathrm{mmol}, 1$ eq.) in benzene (60 ml) was refluxed overnight with water removal (using a Dean-Stark trap) in the presence of methane sulfonic acid (0.22 $\mathrm{ml}, 3.31 \mathrm{mmol}, 0.5$ eq.). After the solvent evaporation, the residue was diluted with water $(50 \mathrm{ml})$ and neutralized by sodium bicarbonate $\left(\mathrm{NaHCO}_{3}\right.$ satd. soln.). The organic materials were subsequently extracted with DCM $(3 \mathrm{x}$ $50 \mathrm{ml}$ ), the combined organic layers were dried over magnesium sulfate and the solvent evaporated under reduced pressure. The crude product was purified by flash-chromatography (PE / EtOAc 8/2) to give the pure annulation product 3. $\mathrm{C}_{10} \mathrm{H}_{14} \mathrm{O}$; light brown oil; yield: $60 \% ; \mathrm{M}=150.22 \mathrm{~g} / \mathrm{mol}$; IR $(\mathrm{ZnSe}) v=2933,1714,1671,1452 \mathrm{~cm}^{-}$ ${ }^{1}$; ${ }^{1} \mathrm{H}$ NMR $\left(300 \mathrm{MHz}, \mathrm{CDCl}_{3}\right) \delta$ 1.12-1.66 (m, 4H), 1.79-1.95 (m, 3H), 2.01-2.43 (m, 6H), $5.78(\mathrm{~s}, 1 \mathrm{H}) ;{ }^{13} \mathrm{C}$ NMR $\left(75 \mathrm{MHz}, \mathrm{CDCl}_{3}\right) \delta 25.6\left(\mathrm{CH}_{2}\right), 27.0\left(\mathrm{CH}_{2}\right), 29.3\left(\mathrm{CH}_{2}\right), 34.5\left(\mathrm{CH}_{2}\right), 35.6\left(\mathrm{CH}_{2}\right), 36.6\left(\mathrm{CH}_{2}\right), 38.0(\mathrm{CH}), 124.4$ $(\mathrm{CH})$; HRMS: calcd. for $\mathrm{C}_{10} \mathrm{H}_{15} \mathrm{O} 151.11174$, found 151.11137 (-2.46 ppm).

\subsubsection{Spiro[4.5]dec-6-ene-1,8-dion (5a)}

To a solution of compound $\mathbf{2 a}(8 \mathrm{~g}, 43.90 \mathrm{mmol})$ in DMSO $(100 \mathrm{ml})$ was added morpholine $(3.90 \mathrm{~g}, 45.27$ $\mathrm{mmol})$ and $\mathrm{AcOH}(2.7 \mathrm{ml}, 45.27 \mathrm{mmol})$ at room temperature under Ar atmosphere. The reaction mixture was stirred at room temperature for $20 \mathrm{~h}$. TLC analysis showed the complete consumption of starting material. The reaction was quenched with saturated aqueous $\mathrm{Na}_{2} \mathrm{CO}_{3}$ solution and extracted with EtOAc $(50 \mathrm{ml} \times 4)$. The combined organic phase was washed with saturated aqueous $\mathrm{NH}_{4} \mathrm{Cl}$ solution $(50 \mathrm{ml})$. The organic phase was dried over $\mathrm{Na}_{2} \mathrm{SO}_{4}$, filtered and concentrated under reduced pressure to give a residue. The resulting residue was purified by column chromatography (neutral alumina; eluent: EtOAc/PE 1/9) to afford the derivative 5a (2.5 g). $\mathrm{C}_{10} \mathrm{H}_{12} \mathrm{O}_{2} ; \mathrm{M}=164.08 \mathrm{~g} / \mathrm{mol}$; yield: $34 \%$; IR $\left(\mathrm{KBr}, \mathrm{cm}^{-1}\right): 2958,1736,1680 ;{ }^{1} \mathrm{H} \mathrm{NMR}\left(400 \mathrm{MHz} ; \mathrm{CDCl}_{3}\right): 1.86-$ $2.13(\mathrm{~m}, 6 \mathrm{H}), 2.28-2.35(\mathrm{~m}, 2 \mathrm{H}), 2.39-2.47(\mathrm{~m}, 1 \mathrm{H}), 2.58-2.66(\mathrm{~m}, 1 \mathrm{H}), 6.02(\mathrm{~d}, \mathrm{~J}=10.0 \mathrm{~Hz}, 1 \mathrm{H}), 6.48(\mathrm{~d}, \mathrm{~J}=$ $10.0 \mathrm{~Hz}, 1 \mathrm{H}) ;{ }^{13} \mathrm{C}$ NMR $\left(100 \mathrm{MHz} ; \mathrm{CDCl}_{3}\right): 19.09,30.04,33.47,36.38,37.24,51.29,130.48,149.89,198.60$, 217.06. MS (APCI): $\mathrm{m} / \mathrm{z}=165[\mathrm{M}+\mathrm{H}]^{+}$.

\subsubsection{Spiro[5.5]undec-10-ene-5,9-dione (5b)}

Under inert atmosphere, morpholine $(6.66 \mathrm{ml}, 1$ eq.) and acetic acid $(4.4 \mathrm{ml}, 1$ eq.) were added to a solution of the previously obtained Michel adduct $2 \mathbf{b}(15 \mathrm{~g}, 1$ eq.) in DMSO $(130 \mathrm{ml})$. The mixture was vigorously stirred for $48 \mathrm{~h}$ at room temperature, then, after the complete consumption of the starting material, slowly added to sodium carbonate (satd. soln., $100 \mathrm{ml}$ ). The organics were extracted with ethyl acetate $(4 \mathrm{x} 50 \mathrm{ml})$, then washed with ammonium chloride $(100 \mathrm{ml})$ before drying over magnesium sulfate. The solvent was evaporated under reduced pressure and the crude product was purified by flash chromatography (PE / EtOAc 7/3) to give the desired annulated compound $\mathbf{5 b}$ as a colourless oil $(10 \mathrm{~g}) . \mathrm{C}_{11} \mathrm{H}_{14} \mathrm{O}_{2}$; colourless oil; yield: $73 \% ; \mathrm{M}=178.23 \mathrm{~g} / \mathrm{mol}$; IR $(\mathrm{ZnSe}) v=2939,1703,1680,1125 \mathrm{~cm}^{-1} ;{ }^{1} \mathrm{H}$ NMR (300 MHz, CDCl3) $\delta 1.88-2.05(\mathrm{~m}, 5 \mathrm{H}), 2.30-2.61(\mathrm{~m}, 5 \mathrm{H})$, $6.02(\mathrm{dd}, \mathrm{J}=10.2 \mathrm{~Hz}, \mathrm{~J}=7.8 \mathrm{~Hz}, 1 \mathrm{H}), 6.95(\mathrm{dd}, \mathrm{J}=10.2 \mathrm{~Hz}, \mathrm{~J}=4.5 \mathrm{~Hz}, 1 \mathrm{H}) ;{ }^{13} \mathrm{C} \mathrm{NMR}(75 \mathrm{MHz}, \mathrm{CDCl} 3) \delta 20.9$ $\left(\mathrm{CH}_{2}\right), 27.6\left(\mathrm{CH}_{2}\right), 30.5\left(\mathrm{CH}_{2}\right), 34.0\left(\mathrm{CH}_{2}\right), 38.3\left(\mathrm{CH}_{2}\right), 39.2\left(\mathrm{CH}_{2}\right), 51.2\left(\mathrm{C}_{\mathrm{q}}\right), 129.7(\mathrm{CH}), 150.8(\mathrm{CH}), 198.7$ $\left(\mathrm{C}_{\mathrm{q}}\right), 210.9\left(\mathrm{C}_{\mathrm{q}}\right)$; HRMS: calcd. for $\mathrm{C}_{11} \mathrm{H}_{14} \mathrm{O}_{2} \mathrm{Na}$ 201.0886, found 201.0887 (0.3737 ppm).

\subsubsection{1,4-Dioxadispiro[4.0.5.3]tetradec-7-en-9-one (6a)}

To a suspension of compound 5a $(4 \mathrm{~g}, 24.38 \mathrm{mmol})$ in ethylene glycol $(40 \mathrm{ml})$ was added (+)-camphor sulfonic acid $(1.69 \mathrm{~g}, 7.3 \mathrm{mmol})$ and $4 \AA$ molecular sieves $(12 \mathrm{~g})$ at $0^{\circ} \mathrm{C}$ under $\mathrm{Ar}$ atmosphere. The reaction mixture was allowed to stir for $40 \mathrm{~min}$ at room temperature. The reaction mixture was filtered and the filtrates was poured into saturated aqueous $\mathrm{NaHCO}_{3}$ solution $(50 \mathrm{ml})$ and extracted with EtOAc $(100 \mathrm{ml} \times 3)$. The combined organic phase was washed with brine solution, dried over $\mathrm{Na}_{2} \mathrm{SO}_{4}$, filtered and concentrated under reduced pressure to give a residue. The residue was purified by column chromatography (neutral alumina; eluent: 
EtOAc/PE 1/4)) to give the ketal 6a $(1 \mathrm{~g}, 69 \%) . \mathrm{C}_{12} \mathrm{H}_{16} \mathrm{O}_{3}$; yellow liquid; yield: $69 \%$; $\mathrm{M}=208.11 \mathrm{~g} / \mathrm{mol}$; IR (KBr): 2953, $1680 \mathrm{~cm}^{-1} ;{ }_{1}^{1} \mathrm{H}$ NMR (400 MHz; $\left.\mathrm{CDCl}_{3}\right): 1.76-2.00(\mathrm{~m}, 7 \mathrm{H}), 2.19-2.26(\mathrm{~m}, 1 \mathrm{H}), 2.35-2.43(\mathrm{~m}, 1 \mathrm{H})$, 2.56-2.62 (m, 1H), 3.85-3.94 (m, 4H), $5.97(\mathrm{~d}, \mathrm{~J}=10.4 \mathrm{~Hz}, 1 \mathrm{H}), 6.92(\mathrm{~d}, \mathrm{~J}=10.0 \mathrm{~Hz}, 1 \mathrm{H}) ;{ }^{13} \mathrm{C} \mathrm{NMR}(100 \mathrm{MHz}$; $\left.\mathrm{CDCl}_{3}\right): 18.53,28.51,33.86,34.52,34.58,48.42,64.83,65.25,119.54,128.86,153.80,199.91 ; \mathrm{MS}$ (APCI): m/z $=209.0(\mathrm{M}+1)$;

\subsubsection{1,4-dioxadispiro[4.0.5-6.4-5]pentadec-7-en-9-one ( $6 \boldsymbol{b})$}

Under nitrogen atmosphere, to a solution of the spiro-derivative $\mathbf{5 b}(5 \mathrm{~g}, 1$ eq.) in ethylene glycol (50 $\mathrm{ml})$, were successively added PTSA (5.35 g, 1 eq.) and activated molecular sieves $(5 \mathrm{~g})$. After $1 \mathrm{~h}$ of reaction, the mixture was poured in a water / sodium bicarbonate (satd. soln.) mixture $(2 / 1,100 \mathrm{ml})$, then extracted with ethyl acetate (3 $\mathrm{x} 150 \mathrm{ml})$. The combined organic layers were washed with brine $(100 \mathrm{ml})$, dried over magnesium sulfate and the solvent evaporated under vacuum. The desired ketal was purified by flash-chromatography (PE/EtOAc 9/1) and isolated as a light-yellow oil. $\mathrm{C}_{13} \mathrm{H}_{18} \mathrm{O}_{3}$; light-yellow visc. oil; yield: $72 \% ; \mathrm{M}=222.28 \mathrm{~g} / \mathrm{mol}$; IR $(\mathrm{ZnSe}) v=$ 2936, 1679, 1448, $1088 \mathrm{~cm}^{-1}$; ${ }^{1} \mathrm{H}$ NMR $(300 \mathrm{MHz}, \mathrm{CDCl} 3) \delta 1.41-1.55(\mathrm{~m}, 2 \mathrm{H}), 1.58-1.64(\mathrm{~m}, 5 \mathrm{H}), 1.75-1.95(\mathrm{~m}$, 2H), 2.21-2.44 (m, 2H), 2.50-2.59 (m, 1H), 3.84-3.97 (m, 4H), $5.96(\mathrm{dd}, \mathrm{J}=10.4 \mathrm{~Hz}, \mathrm{~J}=1.3 \mathrm{~Hz}, 1 \mathrm{H}), 6.95(\mathrm{~d}, \mathrm{~J}=$ $10.5 \mathrm{~Hz}) ;{ }^{13} \mathrm{C}$ NMR $\left(75 \mathrm{MHz}, \mathrm{CDCl}_{3}\right) \delta 20.8\left(\mathrm{CH}_{2}\right), 23.4\left(\mathrm{CH}_{2}\right), 27.6\left(\mathrm{CH}_{2}\right), 30.8\left(\mathrm{CH}_{2}\right), 33.9\left(\mathrm{CH}_{2}\right), 33.9\left(\mathrm{CH}_{2}\right)$, $44.1\left(\mathrm{C}_{\mathrm{q}}\right), 65.1\left(\mathrm{CH}_{2}\right), 65.2\left(\mathrm{CH}_{2}\right), 111.7\left(\mathrm{C}_{\mathrm{q}}\right), 129.4(\mathrm{CH}), 154.6(\mathrm{CH}), 200.0\left(\mathrm{C}_{\mathrm{q}}\right)$; HRMS: calcd. for $\mathrm{C}_{13} \mathrm{H}_{18} \mathrm{O}_{3} \mathrm{Na}$ 245.1154 , found 245.1147 (-0.5494 ppm).

\subsubsection{2-hydroxyethyl 4-(1,4-dioxaspiro[4.5]dec-8-en-8-yl)butanoate (7)}

Under nitrogen atmosphere, to a solution of the spiro derivative $\mathbf{5 b}(5 \mathrm{~g}, 30.47 \mathrm{mmol}, 1 \mathrm{eq}$.) in ethylene glycol $(50 \mathrm{ml})$, were successively added PTSA $(5.8 \mathrm{~g}, 30.47 \mathrm{mmol}, 1 \mathrm{eq}$.) and activated molecular sieves $(8 \mathrm{~g})$. After $1 \mathrm{~h}$ of reaction, the mixture was poured in a water / sodium bicarbonate (satd. soln.) mixture $(2 / 1,100 \mathrm{ml})$, then extracted with ethyl acetate $(3 \times 150 \mathrm{ml})$. The combined organic layers were washed with brine $(100 \mathrm{ml})$, dried over magnesium sulfate and the solvent evaporated under vacuum. The ketal was isolated by flashchromatography (PE/EtOAc 8/2) as a colorless oil (5.14 g). $\mathrm{C}_{14} \mathrm{H}_{22} \mathrm{O}_{5}$; colorless oil; yield: 63\%; $\mathrm{M}=270.32 \mathrm{~g} /$ mol; IR (ZnSe) $v=3492,2952,1733,1452,1382,1254,1116 \mathrm{~cm}^{-1} ;{ }^{1} \mathrm{H}$ NMR $(300 \mathrm{MHz}, \mathrm{CDCl} 3) \delta 1.66-1.76(\mathrm{~m}$, $3 \mathrm{H}), 1.97(\mathrm{t}, \mathrm{J}=7.6 \mathrm{~Hz}, 2 \mathrm{H}), 2.09-2.13(\mathrm{~m}, 2 \mathrm{H}), 2.19$ (as, 2H), $2.28(\mathrm{t}, \mathrm{J}=7.5 \mathrm{~Hz}, 2 \mathrm{H}), 2.53(\mathrm{t}, \mathrm{J}=5.8 \mathrm{~Hz}, 1 \mathrm{H})$, 3.73-3.78 (m, 2H), $3.92(\mathrm{~s}, 4 \mathrm{H}), 4.13-4.16(\mathrm{~m}, 2 \mathrm{H}), 5.27(\mathrm{as}, 1 \mathrm{H}) ;{ }^{13} \mathrm{C} \mathrm{NMR}\left(75 \mathrm{MHz}, \mathrm{CDCl}_{3}\right) \delta 22.8\left(\mathrm{CH}_{2}\right), 27.3$ $\left(\mathrm{CH}_{2}\right), 31.1\left(\mathrm{CH}_{2}\right), 33.6\left(\mathrm{CH}_{2}\right), 35.6\left(\mathrm{CH}_{2}\right), 36.3\left(\mathrm{CH}_{2}\right), 61.0\left(\mathrm{CH}_{2}\right), 64.4\left(2 \mathrm{CH}_{2}\right), 65.9\left(\mathrm{CH}_{2}\right), 108.1\left(\mathrm{C}_{\mathrm{q}}\right), 118.9$ $(\mathrm{CH}), 136.4\left(\mathrm{C}_{\mathrm{q}}\right), 174.0\left(\mathrm{C}_{\mathrm{q}}\right) ; \mathrm{MS} \mathrm{m} / \mathrm{z}=271.1[\mathrm{M}+\mathrm{H}]^{+}$; HRMS: calcd. for $\mathrm{C}_{14} \mathrm{H}_{23} \mathrm{O}_{5}$ 271.15540, found 271.15509 (4.019 ppm).

\subsubsection{Ethyl 4-(1,4-dioxaspiro[4.5]dec-8-en-8-yl)butanoate}

Sodium hydride (60\% dispersion in mineral oil, $6.4 \mathrm{~g}$ ) was added under nitrogen to a dry solution of compound $7(8.3 \mathrm{~g}, 39.9 \mathrm{mmol})$ in toluene $(80 \mathrm{ml})$. The mixture was cooled to $-40^{\circ} \mathrm{C}$, stirred for $10 \mathrm{~min}$ at low temperature before addition of $0.1 \mathrm{ml}$ of dry methanol. The mixture was left to come back to room temperature, an, after complete consumption of starting material, the mixture was slowly poured onto ice-cold water. The organics were extracted with ethyl acetate $(100 \mathrm{ml} \times 3)$. The combined organic layers were dried over magnesium sulfate, then the solvent was evaporated under vacuum. The crude product was further purified by flash chromatography (eluent PE / EtOAc 7/3) to conduct to the ring-opening product. $\mathrm{C}_{14} \mathrm{H}_{22} \mathrm{O}_{4}$; colorless oil; yield: $77 \% ; \mathrm{M}=254.32 \mathrm{~g}$ / mol; IR (ZnSe) $v=2952,1736,1375,1116 \mathrm{~cm}^{-1}$; ${ }^{1} \mathrm{H}$ NMR $(300 \mathrm{MHz}, \mathrm{CDCl} 3) \delta 1.19(\mathrm{t}, \mathrm{J}=7.1 \mathrm{~Hz}, 3 \mathrm{H}), 1.65-$ $1.75(\mathrm{~m}, 4 \mathrm{H}), 1.96(\mathrm{t}, \mathrm{J}=7.4 \mathrm{~Hz}, 2 \mathrm{H}), 2.09-2.13(\mathrm{~m}, 2 \mathrm{H}), 2.20-2.25(\mathrm{~m}, 4 \mathrm{H}), 3.92(\mathrm{~s}, 4 \mathrm{H}), 4.06(\mathrm{q}, \mathrm{J}=7.1 \mathrm{~Hz}, 2 \mathrm{H})$, 5.27 (as, 1H); ${ }^{13} \mathrm{C}$ NMR $(75 \mathrm{MHz}, \mathrm{CDCl} 3) \delta 14.2\left(\mathrm{CH}_{3}\right), 22.9\left(\mathrm{CH}_{2}\right), 27.3\left(\mathrm{CH}_{2}\right), 31.1\left(\mathrm{CH}_{2}\right), 33.8\left(\mathrm{CH}_{2}\right), 35.6$ $\left(\mathrm{CH}_{2}\right), 36.3\left(\mathrm{CH}_{2}\right), 60.1\left(\mathrm{CH}_{2}\right), 64.2\left(2 \mathrm{CH}_{2}\right), 108.0\left(\mathrm{C}_{\mathrm{q}}\right), 118.8(\mathrm{CH}), 136.5\left(\mathrm{C}_{\mathrm{q}}\right), 173.6(\mathrm{Cq}) ; \mathrm{MS} \mathrm{m} / \mathrm{z}=255.1$ $[\mathrm{M}+\mathrm{H}]^{+}$; HRMS: calcd. for $\mathrm{C}_{14} \mathrm{H}_{23} \mathrm{O}_{4} 255.16048$, found 255.15995 (3.387 ppm).

\subsubsection{1-(4-fluorophenyl)spiro[4H-indazole-5-2'-cyclopentane]-1'-one-ethylelene-acetal (9a)}

To a cooled solution $\left(-40^{\circ} \mathrm{C}\right)$ of ketal $6 \mathbf{a}(1 \mathrm{~g}, 4.80 \mathrm{mmol})$ in anhydrous toluene $(30 \mathrm{ml})$ was added ethyl formate $(1.55 \mathrm{ml}, 19.22 \mathrm{mmol})$ and $\mathrm{NaH}(768 \mathrm{mg}, 60 \%$ on mineral oil, $19.22 \mathrm{mmol})$ under Ar atmosphere. The reaction mixture was stirred for $10 \mathrm{~min}$ at $-40^{\circ} \mathrm{C}$, then $\mathrm{MeOH}(97 \mu \mathrm{l}, 2.4 \mathrm{mmol})$ was added. Reaction mixture was left to come back to room temperature and stirred for 10 additional minutes. TLC analysis showed the complete consumption of starting material. The reaction mixture was poured into ice-cold water $(20 \mathrm{ml})$ and extracted with EtOAc $(50 \mathrm{ml} \times 4)$. The combined organic phase was washed with brine solution $(25 \mathrm{ml})$, dried over $\mathrm{Na}_{2} \mathrm{SO}_{4}$ and evaporated under vacuum to give the crude $\alpha$-formylation product $\left(1.09 \mathrm{~g}, 96 \%\right.$, pale yellow liquid). $\mathrm{IR}\left(\mathrm{KBr}, \mathrm{cm}^{-}\right.$ $\left.{ }^{1}\right): 2925,1644 .{ }^{1} \mathrm{H}$ NMR (400 MHz; $\left.\mathrm{CDCl}_{3}\right): 1.72-1.82$ (m, 4H), 1.90-2.04 (m, 2H), $2.22(\mathrm{~d}, \mathrm{~J}=14.4 \mathrm{~Hz}, 1 \mathrm{H})$, 
$2.73(\mathrm{~d}, \mathrm{~J}=14.8 \mathrm{~Hz}, 1 \mathrm{H}), 3.90-3.95(\mathrm{~m}, 4 \mathrm{H}), 6.06(\mathrm{~d}, \mathrm{~J}=10.0 \mathrm{~Hz}, 1 \mathrm{H}), 6.83(\mathrm{~d}, \mathrm{~J}=10.0 \mathrm{~Hz}, 1 \mathrm{H}), 7.47$ (bs, $1 \mathrm{H}), 13.65(\mathrm{bs}, 1 \mathrm{H})$.

To a solution of the previously obtained crude product $(1.05 \mathrm{~g}, 4.44 \mathrm{mmol})$ in acetic acid $(20 \mathrm{ml})$ was added $\mathrm{NaOAc}(730 \mathrm{mg}, 8.89 \mathrm{mmol})$ and 4-fluorophenyl hydrazine chlorhydrate $(795 \mathrm{mg}, 4.89 \mathrm{mmol})$ at room temperature. The reaction mixture was stirred at room temperature for $30 \mathrm{~min}$. TLC analysis showed the complete consumption of starting material. Then, the reaction mixture was poured into ice-cold saturated aqueous $\mathrm{Na} 2 \mathrm{CO} 3$ solution $(20 \mathrm{ml})$ and extracted with EtOAc $(50 \mathrm{ml} \times 4)$. The combined organic phase was washed with brine $(25$ $\mathrm{ml}$ ), dried over Na2SO4 and purified over neutral alumina (PE/EtOAc 9/1). The collected fraction was evaporated under vacuum to give the title compound $9 \mathrm{a}(930 \mathrm{mg}) . \mathrm{C}_{19} \mathrm{H}_{19} \mathrm{FN}_{2} \mathrm{O}_{2}$; pale yellow oil; yield: $64 \% ; \mathrm{M}=326.14 \mathrm{~g} /$ mol; IR (KBr): 2922, 2322, $1514 \mathrm{~cm}^{-1} ;{ }^{1} \mathrm{H}$ NMR (400 MHz; $\mathrm{CDCl}_{3}$ ): 1.72-1.85 (m, 4H), 1.93-1.98 (m, 2H), 2.62 $(\mathrm{d}, \mathrm{J}=17.6 \mathrm{~Hz}, 1 \mathrm{H}), 3.00(\mathrm{~d}, \mathrm{~J}=16 \mathrm{~Hz}, 1 \mathrm{H}), 3.90-3.94(\mathrm{~m}, 4 \mathrm{H}), 6.04(\mathrm{~d}, \mathrm{~J}=10.4 \mathrm{~Hz}, 1 \mathrm{H}), 6.44(\mathrm{~d}, \mathrm{~J}=10.0 \mathrm{~Hz}$, 1H), 7.12-7.17 (m, 2H), 7.43-7.47 (m, 3H). ${ }^{13} \mathrm{C}$ NMR (400 MHz; $\left.\mathrm{CDCl}_{3}\right): 17.85,25.64,33.82,35.07,49.82$, $65.19,65.20,115.25,115.49,115.94,116.17,119.25,125.10,125.19,134.78,138.01,160.25,162.71 ; \mathrm{MS}: \mathrm{m} / \mathrm{z}=$ $327[\mathrm{M}+1]^{+}$.

\subsubsection{1-(4-fluorophenyl)spiro[4H-indazole-5,2'-cyclohexane]-1'-one-ethylene-acetal (9b)}

Under inert atmosphere, the previously obtained ketal $\mathbf{6 b}(4.90 \mathrm{~g}, 1$ eq.) was dissolved in dry toluene (150 ml) and the mixture cooled to $-40^{\circ} \mathrm{C}$. Ethyl formate $(7.1 \mathrm{ml}, 4$ eq.) and then sodium hydride $(60 \%$ dispersion in oil, 3.5 g, 4 eq.) were subsequently added before slowly add methanol $(0.44 \mathrm{ml}, 0.5$ eq. $)$ at low temperature over 15 minutes. The mixture was stirred for $30 \mathrm{~min}$ at low temperature, then left to slowly come back to room temperature and stirred for two additional hours. After the complete consumption of the starting material, the mixture was slowly poured onto ice-cold water $(100 \mathrm{ml})$, the organic layer was separated and washed two additional times with water $(2 \times 75 \mathrm{ml})$. The combined aqueous layers were subsequently acidified to with hydrogen chloride (aq. soln., $6 \mathrm{~N}$ ) before extracting the organic materials with diethyl ether $(3 \mathrm{x} 100 \mathrm{ml})$. The combined organic layers were dried over magnesium sulfate and the solvent evaporated to give a light yellow oil turning brown on standing $(4.47 \mathrm{~g})$ which was subsequently used without further purification. $\mathrm{C}_{14} \mathrm{H}_{18} \mathrm{O}_{4}$; lightyellow oil; yield: $84 \% ; \mathrm{M}=250.29 \mathrm{~g} / \mathrm{mol}$; IR $\left(\mathrm{SeO}_{2}\right) v=2937,1645,1186,1086 \mathrm{~cm}^{-1}$; ${ }^{1} \mathrm{H} \mathrm{NMR}(300 \mathrm{MHz}$, $\mathrm{CDCl} 3) \delta 1.41-1.47(\mathrm{~m}, 2 \mathrm{H}), 1.51-1.75(\mathrm{~m}, 6 \mathrm{H}), 2.33(\mathrm{dd}, \mathrm{J}=14.7 \mathrm{~Hz}, \mathrm{~J}=1.2 \mathrm{~Hz}, 1 \mathrm{H}), 2.76(\mathrm{dd}, \mathrm{J}=14.6 \mathrm{~Hz}, \mathrm{~J}=$ $1.3 \mathrm{~Hz}, 1 \mathrm{H}), 3.90-4.01(\mathrm{~m}, 4 \mathrm{H}), 6.06(\mathrm{~d}, \mathrm{~J}=10.3 \mathrm{~Hz}, 1 \mathrm{H}), 6.91(\mathrm{dd}, \mathrm{J}=10.3 \mathrm{~Hz}, \mathrm{~J}=1.5 \mathrm{~Hz}, 1 \mathrm{H}), 7.43(\mathrm{~s}, 1 \mathrm{H})$, $13.66(\mathrm{~s}, 1 \mathrm{H}) ;{ }^{13} \mathrm{C}$ NMR $\left(75 \mathrm{MHz}, \mathrm{CDCl}_{3}\right) \delta 21.0\left(\mathrm{CH}_{2}\right), 23.4\left(\mathrm{CH}_{2}\right), 28.8\left(\mathrm{CH}_{2}\right), 30.7\left(\mathrm{CH}_{2}\right), 33.8\left(\mathrm{CH}_{2}\right), 45.3$ $\left(\mathrm{C}_{\mathrm{q}}\right), 65.1\left(\mathrm{CH}_{2}\right), 65.3\left(\mathrm{CH}_{2}\right), 106.6\left(\mathrm{C}_{\mathrm{q}}\right), 111.2\left(\mathrm{C}_{\mathrm{q}}\right), 128.2(\mathrm{CH}), 152.5(\mathrm{CH}), 166.4(\mathrm{CH}), 189.2\left(\mathrm{C}_{\mathrm{q}}\right) ; \mathrm{MS}: \mathrm{m} / \mathrm{z}=$ $249.2[\mathrm{M}-\mathrm{H}]^{+}$; HRMS: calcd. for $\mathrm{C}_{14} \mathrm{H}_{17} \mathrm{O}_{4} 249.1121$, found 249.1126 (1.8817 ppm).

At room temperature, sodium acetate $(0.31 \mathrm{~g}, 1.1 \mathrm{eq}$. $)$ and 4-F-phenylhydrazine $(0.61 \mathrm{~g}, 1.1 \mathrm{eq}$.) were added to a solution of the previously-obtained $\alpha$-formylation product $(0.85 \mathrm{~g}, 1 \mathrm{eq}$. $)$ in acetic acid $(15 \mathrm{ml})$. The mixture was stirred until the complete consumption of the starting material (approx. $1.5 \mathrm{~h}$ ), then the reaction was quenched by addition of sodium carbonate (sat. soln. $100 \mathrm{ml})$. The aqueous mixture was washed with ethyl acetate $(3 \times 100$ $\mathrm{ml}$ ), the combined organic layers were dried over magnesium sulfate and the solvent evaporated under reduced pressure. The crude product was subsequently purified by flash-chromatography (eluent: $\mathrm{PE} / \mathrm{EtOAc} 8 / 2$ ) to conduct to the desired indazole derivative $9 \mathbf{b}$, isolated as a light yellow visc. oil. $\mathrm{C}_{20} \mathrm{H}_{21} \mathrm{FN}_{2} \mathrm{O}_{2}$; light-yellow visc. oil; yield: $87 \% ; \mathrm{M}=340.39 \mathrm{~g} / \mathrm{mol}$; IR $(\mathrm{ZnSe}) v=2936,1515,1222,840 \mathrm{~cm}^{-1} ;{ }^{1} \mathrm{H} \mathrm{NMR}\left(300 \mathrm{MHz}, \mathrm{CDCl}_{3}\right) \delta$ 1.78-1.36 (m, 8H), $2.74(\mathrm{~d}, \mathrm{~J}=16.0 \mathrm{~Hz}, 1 \mathrm{H}), 2.97(\mathrm{~d}, \mathrm{~J}=16.0 \mathrm{~Hz}, 1 \mathrm{H}), 3.97-3.98(\mathrm{~m}, 4 \mathrm{H}), 6.09(\mathrm{~d}, \mathrm{~J}=10.3 \mathrm{~Hz}$, $1 \mathrm{H}), 6.43(\mathrm{~d}, \mathrm{~J}=10.3 \mathrm{~Hz}, 1 \mathrm{H}), 7.10-7.15(\mathrm{~m}, 2 \mathrm{H}), 7.41-7.46(\mathrm{~m}, 3 \mathrm{H}) ;{ }^{13} \mathrm{C} \mathrm{NMR}(75 \mathrm{MHz}, \mathrm{CDCl} 3) \delta 20.5\left(\mathrm{CH}_{2}\right)$, $23.4\left(\mathrm{CH}_{2}\right), 25.1\left(\mathrm{CH}_{2}\right), 30.8\left(\mathrm{CH}_{2}\right), 33.6\left(\mathrm{CH}_{2}\right), 45.7\left(\mathrm{C}_{\mathrm{q}}\right), 65.3\left(\mathrm{CH}_{2}\right), 65.3\left(\mathrm{CH}_{2}\right), 111.8\left(\mathrm{C}_{\mathrm{q}}\right), 115.1(\mathrm{CH}), 115.4$ $\left(\mathrm{C}_{\mathrm{q}}\right), 116.0(\mathrm{CH}), 116.3(\mathrm{CH}), 125.1(\mathrm{CH}), 125.2(\mathrm{CH}), 135.7(\mathrm{CH}), 136.5\left(\mathrm{C}_{\mathrm{q}}\right), 138.4(\mathrm{CH}), 159.9\left(\mathrm{C}_{\mathrm{q}}\right), 163.1$ $\left(\mathrm{C}_{\mathrm{q}}\right) ; \mathrm{MS}: \mathrm{m} / \mathrm{z}=341.2[\mathrm{M}+\mathrm{H}]^{+}$; HRMS: calcd. for $\mathrm{C}_{20} \mathrm{H}_{21} \mathrm{FN}_{2} \mathrm{O}_{2} 341.1660$, found 341.1654 (-1.7188 ppm).

\subsubsection{1-(4-fluorophenyl)spiro[4H-indazole-5-2'-cyclopentane]-1'-one (10a)}

To a solution of ketal $9 \mathbf{a}(930 \mathrm{mg}, 2.85 \mathrm{mmol})$ in THF $(27 \mathrm{ml})$ was added $6 \mathrm{M}$ aqueous $\mathrm{HCl}(14 \mathrm{ml})$ and the reaction mixture was stirred at room temperature for $10 \mathrm{~min}$. TLC analysis showed the complete consumption of starting material. Then, the reaction mixture was poured into saturated aqueous $\mathrm{NaHCO}_{3}$ solution (30ml) and extracted with EtOAc $(50 \mathrm{ml} \times 4)$. The combined organic phase was washed with brine solution $(25 \mathrm{ml})$, dried over $\mathrm{Na}_{2} \mathrm{SO}_{4}$ and evaporated under vacuum to give residual thick oil. The residue was purified by column chromatography (neutral alumina, eluent: PE/EtOAc 9/1) to afford the desired ketone 10a (530 mg). $\mathrm{C}_{17} \mathrm{H}_{15} \mathrm{FN}_{2} \mathrm{O}$; pale yellow liquid; yield: $66 \% ; \mathrm{M}=282.32 \mathrm{~g} / \mathrm{mol}$; $\mathrm{IR}(\mathrm{KBr}): 1737,1514 \mathrm{~cm}^{-1} ;{ }^{1} \mathrm{H} \mathrm{NMR}\left(400 \mathrm{MHz} ; \mathrm{CDCl}_{3}\right): 1.90-$ $2.11(\mathrm{~m}, 4 \mathrm{H}), 2.37-2.41(\mathrm{~m}, 2 \mathrm{H}), 2.70(\mathrm{~d}, \mathrm{~J}=16.0 \mathrm{~Hz}, 1 \mathrm{H}), 2.95(\mathrm{~d}, \mathrm{~J}=16.0 \mathrm{~Hz}, 1 \mathrm{H}), 5.69(\mathrm{~d}, \mathrm{~J}=9.6 \mathrm{~Hz}, 1 \mathrm{H})$, $6.54(\mathrm{~d}, \mathrm{~J}=10.0 \mathrm{~Hz}, 1 \mathrm{H}), 7.12-7.16(\mathrm{~m}, 2 \mathrm{H}), 7.41-7.46(\mathrm{~m}, 3 \mathrm{H}) ;{ }^{13} \mathrm{C}$ NMR $(400 \mathrm{MHz} ; \mathrm{CDCl}$ ): 18.57, 27.16, 

$282.9[\mathrm{M}+1]^{+}$;

\subsubsection{1-(4-fluorophenyl)spiro[4H-indazole-5,2'-cyclohexane]-1'-one (10b)}

The ketal moiety of compound $\mathbf{9 b}$ was deprotected by adding hydrogen chloride (aq. soln. $6 \mathrm{~N}, 15 \mathrm{ml}$ ) to a solution of indazole $9 \mathrm{~b}\left(1 \mathrm{~g}, 1\right.$ eq.) in THF $(30 \mathrm{ml})$. The reaction was conducted at $65^{\circ} \mathrm{C}$ for $1.5 \mathrm{~h}$, and then quenched by pouring onto a solution of sodium bicarbonate $(10 \%$ aq. soln. $100 \mathrm{ml})$. The aqueous solution was washed with ethyl acetate $(3 \times 100 \mathrm{ml})$, then the combined organic layers were dried over magnesium sulfate and the solvent evaporated under vacuum. The desired ketone 10b was isolated as a white solid after purification on flash chromatography (eluent $\mathrm{PE} / \mathrm{EtOAc} 8 / 2$ ). $\mathrm{C}_{18} \mathrm{H}_{17} \mathrm{FN}_{2} \mathrm{O}$; white solid; $\mathrm{Mp}=91-93^{\circ} \mathrm{C}$; yield: $71 \% ; \mathrm{M}=296.34 \mathrm{~g}$ / mol; IR (ZnSe) $v=2936,1706,1515,1222,840 \mathrm{~cm}^{-1}$; ${ }^{1} \mathrm{H}$ NMR $(300 \mathrm{MHz}, \mathrm{CDCl} 3) \delta 1.74-1.93(\mathrm{~m}, 6 \mathrm{H}), 2.40-$ $2.49(\mathrm{~m}, 1 \mathrm{H}), 2.52-2.61(\mathrm{~m}, 1 \mathrm{H}), 2.77(\mathrm{~d}, \mathrm{~J}=16.0 \mathrm{~Hz}, 1 \mathrm{H}), 3.13(\mathrm{~d}, \mathrm{~J}=16.0 \mathrm{~Hz}, 1 \mathrm{H}), 6.10(\mathrm{~d}, \mathrm{~J}=10.1 \mathrm{~Hz}, 1 \mathrm{H})$, $6.48(\mathrm{dd}, \mathrm{J}=10.1 \mathrm{~Hz}, \mathrm{~J}=0.5 \mathrm{~Hz}, 1 \mathrm{H}), 7.10-7.16(\mathrm{~m}, 2 \mathrm{H}), 7.40-7.45(\mathrm{~m}, 3 \mathrm{H}) ;{ }^{13} \mathrm{C}$ NMR $\left(75 \mathrm{MHz}, \mathrm{CDCl}_{3}\right) \delta 20.9$ $\left(\mathrm{CH}_{2}\right), 27.3\left(\mathrm{CH}_{2}\right), 27.8\left(\mathrm{CH}_{2}\right), 37.7\left(\mathrm{CH}_{2}\right), 38.8\left(\mathrm{CH}_{2}\right), 52.0\left(\mathrm{C}_{\mathrm{q}}\right), 114.7\left(\mathrm{C}_{\mathrm{q}}\right), 116.0(\mathrm{CH}), 116.2(\mathrm{CH}), 116.3$ $(\mathrm{CH}), 125.1(\mathrm{CH}), 125.3(\mathrm{CH}), 132.6(\mathrm{CH}), 136.1\left(\mathrm{C}_{\mathrm{q}}\right), 138.2(\mathrm{CH}), 160.0\left(\mathrm{C}_{\mathrm{q}}\right), 163.3\left(\mathrm{C}_{\mathrm{q}}\right), 211.5\left(\mathrm{C}_{\mathrm{q}}\right) ; \mathrm{MS}: \mathrm{m} / \mathrm{z}=$ $297.2[\mathrm{M}+\mathrm{H}]^{+}$; HRMS: calcd. for $\mathrm{C}_{18} \mathrm{H}_{18} \mathrm{FN}_{2} \mathrm{O} 297.1398$, found 297.1394 (-1.2857 ppm).

\subsubsection{Reduction of the ketone moieties}

Under inert atmosphere and at $-78^{\circ} \mathrm{C}$, DIBAL-H (1M soln. in THF, $1.02 \mathrm{ml}, 1.02 \mathrm{mmol}, 3$ eq.) was slowly added to a solution of the ketone $10 \mathrm{~b}(0.1 \mathrm{~g}, 0.34 \mathrm{mmol}, 1 \mathrm{eq}$.$) in dry THF (10 \mathrm{ml})$. The reaction mixture was stirred at low temperature for $1 \mathrm{~h}$. The reaction was quenched by addition of water $(20 \mathrm{ml})$ at low temperature then, the organics extracted with ethyl acetate $(3 \times 30 \mathrm{ml})$. The combined organic layers were dried over magnesium sulfate and concentrated under vacuum. The crude product was purified by flash-chromatography (P.E. / EtOAc 7/3) to conduct to the desired product as a 3/1 mixture of diastereoisomers.

1-(4-fluorophenyl)-1'-phenyl-spiro[4H-indazole-5,2'-cyclohexane]-1'-ol (11). (5S, 8R)-diastereoisomer: $\mathrm{C}_{18} \mathrm{H}_{19} \mathrm{FN}_{2} \mathrm{O}$; White solid; $\mathrm{Mp}=164-166^{\circ} \mathrm{C}$; Yield: $22 \%$ (based on the ${ }^{1} \mathrm{H}-\mathrm{NMR}$ ); $\mathrm{M}=298.35 \mathrm{~g} / \mathrm{mol}$; IR $(\mathrm{ZnSe}) v$ $=3302,2941,1514,1222,988,842 ;{ }^{1} \mathrm{H}$ NMR $\left(300 \mathrm{MHz}, \mathrm{CDCl}_{3}\right) \delta 1.34-1.98(\mathrm{~m}, 8 \mathrm{H}), 2.49(\mathrm{~d}, \mathrm{~J}=15.9 \mathrm{~Hz}, 1 \mathrm{H})$, $3.11(\mathrm{~d}, \mathrm{~J}=15.9 \mathrm{~Hz}, 1 \mathrm{H}), 3.54\left(\mathrm{dd}, \mathrm{J}_{1}=9.7 \mathrm{~Hz}, \mathrm{~J}_{2}=4.1 \mathrm{~Hz}, 1 \mathrm{H}\right), 6.13(\mathrm{~d}, \mathrm{~J}=10.3 \mathrm{~Hz}, 1 \mathrm{H}), 6.54(\mathrm{~d}, \mathrm{~J}=10.2 \mathrm{~Hz}$, $1 \mathrm{H})$, 7.15-7.18 (m, 2H), 7.43-7.48 (3H); ${ }^{13} \mathrm{C}$ NMR (75 MHz, CDCl3) $\delta 21.6\left(\mathrm{CH}_{2}\right), 23.8\left(\mathrm{CH}_{2}\right), 30.5\left(\mathrm{CH}_{2}\right), 30.8$ $\left(\mathrm{CH}_{2}\right), 36.0\left(\mathrm{CH}_{2}\right), 42.4\left(\mathrm{C}_{\mathrm{q}}\right), 75.8(\mathrm{CH}), 115.8\left(\mathrm{C}_{\mathrm{q}}\right), 116.1(\mathrm{CH}), 116.4(\mathrm{CH}), 116.6(\mathrm{CH}), 125.2(\mathrm{CH}), 125.3$ $(\mathrm{CH}), 134.4(\mathrm{CH}), 136.9\left(\mathrm{C}_{\mathrm{q}}\right), 138.2(\mathrm{CH}) ; 160.0\left(\mathrm{C}_{\mathrm{q}}\right), 163.3\left(\mathrm{C}_{\mathrm{q}}\right)$.

1-(4-fluorophenyl)-1'-phenyl-spiro[4H-indazole-5,2'-cyclohexane]-1'-ol $\quad$ (12). $\quad$ (5S, 8S)-diastereoisomer: $\mathrm{C}_{18} \mathrm{H}_{19} \mathrm{FN}_{2} \mathrm{O}$; White solid; $\mathrm{Mp}=144-146^{\circ} \mathrm{C}$; Yield: 68\%; $\mathrm{M}=298.35 \mathrm{~g} / \mathrm{mol}$; IR (ZnSe) $v=3320,2926,1517$, $842 \mathrm{~cm}^{-1} ;{ }^{1} \mathrm{H}$ NMR $\left(300 \mathrm{MHz}, \mathrm{CDCl}_{3}\right) \delta 1.18-1.60(\mathrm{~m}, 5 \mathrm{H}), 1.72-1.81(\mathrm{~m}, 3 \mathrm{H}), 2.71(\mathrm{~d}, \mathrm{~J}=16.2 \mathrm{~Hz}, 1 \mathrm{H}), 3.00(\mathrm{~d}$, $\mathrm{J}=16.21 \mathrm{H}), 3.63\left(\mathrm{dd}, \mathrm{J}_{1}=9.7 \mathrm{~Hz}, \mathrm{~J}_{2}=3.4 \mathrm{~Hz}, 1 \mathrm{H}\right), 5.75(\mathrm{~d}, \mathrm{~J}=10.0 \mathrm{~Hz}, 1 \mathrm{H}), 6.48(\mathrm{~d}, \mathrm{~J}=10.0 \mathrm{~Hz}, 1 \mathrm{H}), 7.12-$ $7.18(\mathrm{~m}, 2 \mathrm{H}), 7.43-7.47(\mathrm{~m}, 3 \mathrm{H}) ;{ }^{13} \mathrm{C}$ NMR $\left(75 \mathrm{MHz}, \mathrm{CDCl}_{3}\right) \delta 20.1\left(\mathrm{CH}_{2}\right), 22.1\left(\mathrm{CH}_{2}\right), 23.5\left(\mathrm{CH}_{2}\right), 29.5\left(\mathrm{CH}_{2}\right)$, $32.7\left(\mathrm{CH}_{2}\right), 42.8\left(\mathrm{C}_{\mathrm{q}}\right), 75.4(\mathrm{CH}), 115.4\left(\mathrm{C}_{\mathrm{q}}\right), 116.1(\mathrm{CH}), 116.1(\mathrm{CH}), 116.4(\mathrm{CH}), 125.3(\mathrm{CH}), 125.4(\mathrm{CH}), 136.6$ $\left(\mathrm{C}_{\mathrm{q}}\right), 138.4(\mathrm{CH}), 139.2(\mathrm{CH}), 160.1\left(\mathrm{C}_{\mathrm{q}}\right), 163.3\left(\mathrm{C}_{\mathrm{q}}\right)$; HRMS: calcd. for $\mathrm{C}_{18} \mathrm{H}_{20} \mathrm{FN}_{2} \mathrm{O} 299.15542$, found 299.15534 $(-0.26 \mathrm{ppm})$.

\subsubsection{1-(4-fluorophenyl)-1'-prop-1-ynyl-spiro[4H-indazole-5,2'-cyclohexane]-1'-ol (13a)}

Under inert atmosphere and at $0^{\circ} \mathrm{C}$, the previously obtained ketone $10 \mathrm{~b}(0.3 \mathrm{~g}, 1 \mathrm{eq}$. $)$ was dissolved in dry THF $(10 \mathrm{ml})$. A solution of 1-propynylmagnesium bromide bromide $(0.5 \mathrm{M}$ soln. in THF, $2.04 \mathrm{ml}$, 3 eq.) was slowly added at low temperature and the mixture was stirred 2 additional hours at $0^{\circ} \mathrm{C}$ until the complete conversion of the starting material. The reaction was quenched by addition of ammonium chloride (satd. soln. $30 \mathrm{ml}$ ) and the organic-soluble materials extracted with ethyl acetate $(3 \times 50 \mathrm{ml})$. The organic phase was dried over magnesium sulfate and concentrated under vacuum to give to a crude product. The crude alcohol was subsequently purified by flash chromatography (PE/EtOAc 9/1) to conduct to a white solid which was subsequently crystallized in acetonitrile to give colorless needles. $\mathrm{C}_{21} \mathrm{H}_{21} \mathrm{FN}_{2} \mathrm{O}$; colorless crystals; $\mathrm{Mp}=188-190^{\circ} \mathrm{C}$; Yield: $61 \% ; \mathrm{M}=336.40$ $\mathrm{g} / \mathrm{mol}$; IR (ZnSe) $v=2936,1516,1223,839 \mathrm{~cm}^{-1}$; ${ }^{1} \mathrm{H}$ NMR (300 MHz, DMSO) $\delta 1.24-1.63(\mathrm{~m}, 6 \mathrm{H}), 1.79-1.90$ $(\mathrm{m}, 5 \mathrm{H}), 2.67(\mathrm{~d}, \mathrm{~J}=16.2 \mathrm{~Hz}, 1 \mathrm{H}), 3.00(\mathrm{~d}, \mathrm{~J}=16.2 \mathrm{~Hz}, 1 \mathrm{H}), 5.21(\mathrm{~s}, 1 \mathrm{H}), 6.20(\mathrm{~d}, \mathrm{~J}=10.2 \mathrm{~Hz}, 1 \mathrm{H}), 6.48(\mathrm{~d}, \mathrm{~J}=$ $10.2 \mathrm{~Hz}, 1 \mathrm{H}), 7.32-7.38(\mathrm{~m}, 2 \mathrm{H}), 7.47-7.54(\mathrm{~m}, 3 \mathrm{H}) ;{ }^{13} \mathrm{C}$ NMR $\left(75 \mathrm{MHz}, \mathrm{CDCl}_{3}\right) \delta 3.8\left(\mathrm{CH}_{3}\right), 20.4\left(\mathrm{CH}_{2}\right), 22.5$ $\left(\mathrm{CH}_{2}\right), 32.1\left(\mathrm{CH}_{2}\right), 35.6\left(\mathrm{CH}_{2}\right), 45.5\left(\mathrm{CH}_{2}\right), 92.1\left(\mathrm{C}_{\mathrm{q}}\right), 83.5\left(\mathrm{C}_{\mathrm{q}}\right), 115.7(\mathrm{CH}), 115.8\left(\mathrm{C}_{\mathrm{q}}\right), 116.1(\mathrm{CH}), 116.7(\mathrm{CH})$, $125.1(\mathrm{CH}), 125.2(\mathrm{CH}), 136.5\left(\mathrm{C}_{\mathrm{q}}\right), 137.2(\mathrm{CH}), 138.5(\mathrm{CH}), 160.0\left(\mathrm{C}_{\mathrm{q}}\right), 163.2\left(\mathrm{C}_{\mathrm{q}}\right)$; HRMS: calcd. for $\mathrm{C}_{21} \mathrm{H}_{22} \mathrm{FN}_{2} \mathrm{O} 337.1711$, found 337.1710 (-0.2661 ppm). 


\subsubsection{1'-benzyl-1-(4-fluorophenyl)spiro[4H-indazole-5,2'-cyclohexane]-1'-ol}

Under inert atmosphere and at $0^{\circ} \mathrm{C}$, the previously obtained ketone $\mathbf{1 0 b}(0.3 \mathrm{~g}, 1 \mathrm{eq}$. $)$ was dissolved in dry THF $(10 \mathrm{ml})$. Benzylmagnesium bromide (1M soln. in THF, $1.02 \mathrm{ml}, 3$ eq.) was slowly added at low temperature and the mixture was stirred 2 additional hours at $0^{\circ} \mathrm{C}$ until the complete conversion of the starting material. The reaction was quenched by addition of ammonium chloride (satd. soln. $30 \mathrm{ml}$ ) and the organic-soluble materials extracted with ethyl acetate $(3 \times 50 \mathrm{ml})$. The organic phase was dried over magnesium sulfate and concentrated under vacuum to give to a crude product. This was further purified by flash-chromatography (eluent: PE / EtOAc 9/1) to conduct to the desired diastereoisomers in a 5/1 ratio.

(5S,8R)-1'-benzyl-1-(4-fluorophenyl)spiro[4H-indazole-5,2'-cyclohexane]-1'-ol (13b): $\quad \mathrm{C}_{25} \mathrm{H}_{25} \mathrm{FN}_{2} \mathrm{O}$; White solid; $\mathrm{Mp}=56-58^{\circ} \mathrm{C}$; Yield: $81 \% ; \mathrm{M}=388.48 \mathrm{~g} / \mathrm{mol}$; $\mathrm{IR}(\mathrm{ZnSe}) v=2931,1515,1224,840 \mathrm{~cm}^{-1} ;{ }^{1} \mathrm{H}$ NMR $(300$ $\left.\mathrm{MHz}, \mathrm{CDCl}_{3}\right) \delta 1.41-1.86(\mathrm{~m}, 8 \mathrm{H}), 2.57(\mathrm{~d}, \mathrm{~J}=13.5 \mathrm{~Hz}, 1 \mathrm{H}), 2.67(\mathrm{~d}, \mathrm{~J}=16.6 \mathrm{~Hz}, 1 \mathrm{H}), 3.07(\mathrm{~d}, \mathrm{~J}=13.5 \mathrm{~Hz}, 1 \mathrm{H})$, $3.36(\mathrm{~d}, \mathrm{~J}=16.6 \mathrm{~Hz}, 1 \mathrm{H}), 6.13(\mathrm{~d}, \mathrm{~J}=10.4 \mathrm{~Hz}, 1 \mathrm{H}), 6.51(\mathrm{~d}, \mathrm{~J}=10.3 \mathrm{~Hz}, 1 \mathrm{H}), 7.14-7.34(\mathrm{~m}, 7 \mathrm{H}), 7.46-7.51(\mathrm{~m}$, $3 \mathrm{H}) ;{ }^{13} \mathrm{C}$ NMR $\left(75 \mathrm{MHz}, \mathrm{CDCl}_{3}\right) \delta 21.3\left(\mathrm{CH}_{2}\right), 21.5\left(\mathrm{CH}_{2}\right), 27.2\left(\mathrm{CH}_{2}\right), 32.7\left(\mathrm{CH}_{2}\right), 34.9\left(\mathrm{CH}_{2}\right), 44.1\left(\mathrm{CH}_{2}\right), 44.3$ $\left(\mathrm{C}_{\mathrm{q}}\right), 74.7\left(\mathrm{C}_{\mathrm{q}}\right), 115.2(\mathrm{CH}), 116.0(\mathrm{CH}), 116.3(\mathrm{CH}), 125.2(\mathrm{CH}), 125.2(\mathrm{CH}), 126.6(\mathrm{CH}), 128.3(2 \mathrm{CH}), 131.1$ $(2 \mathrm{CH}), 135.5(\mathrm{CH}), 136.2\left(\mathrm{C}_{q}\right), 137.1\left(\mathrm{C}_{\mathrm{q}}\right), 138.5(\mathrm{CH}), 159.9\left(\mathrm{C}_{\mathrm{q}}\right), 163.2\left(\mathrm{C}_{\mathrm{q}}\right)$; HRMS: calcd. for $\mathrm{C}_{25} \mathrm{H}_{26} \mathrm{FN}_{2} \mathrm{O}$ 389.2014 , found $389.2022(-0.4729 \mathrm{ppm})$.

(5S,8S)-1'-benzyl-1-(4-fluorophenyl)spiro[4H-indazole-5,2'-cyclohexane]-1'-ol $\quad(\mathbf{1 4 b}): \quad \mathrm{C}_{25} \mathrm{H}_{25} \mathrm{FN}_{2} \mathrm{O}$; White solid; $\mathrm{Mp}=73-75^{\circ} \mathrm{C}$; Yield: $13 \%$; $\mathrm{M}=388.48 \mathrm{~g} / \mathrm{mol}$; IR $(\mathrm{ZnSe}) v=3415,2935,1515,1223,839 \mathrm{~cm}^{-1} ;{ }^{1} \mathrm{H}$ NMR $\left(300 \mathrm{MHz}, \mathrm{CDCl}_{3}\right) \delta 1.46-1.93(\mathrm{~m}, 9 \mathrm{H}), 2.85(\mathrm{dd}, \mathrm{J}=35.4 \mathrm{~Hz}, \mathrm{~J}=13.2 \mathrm{~Hz}, 2 \mathrm{H}), 3.00(\mathrm{q}, \mathrm{J}=16.0 \mathrm{~Hz}, 2 \mathrm{H}), 6.35$ $(\mathrm{d}, \mathrm{J}=10.3 \mathrm{~Hz}, 1 \mathrm{H}), 6.54(\mathrm{dd}, \mathrm{J}=10.3 \mathrm{~Hz}, \mathrm{~J}=0.6 \mathrm{~Hz}, 1 \mathrm{H}), 7.17-7.37(\mathrm{~m}, 7 \mathrm{H}), 7.49-7.53(\mathrm{~m}, 3 \mathrm{H}) ;{ }^{13} \mathrm{C} \mathrm{NMR}(75$ $\mathrm{MHz}, \mathrm{CDCl} 3) \delta 20.3\left(\mathrm{CH}_{2}\right), 21.3\left(\mathrm{CH}_{2}\right), 25.2\left(\mathrm{CH}_{2}\right), 31.3\left(\mathrm{CH}_{2}\right), 31.7\left(\mathrm{CH}_{2}\right), 43.7\left(\mathrm{CH}_{2}\right), 45.0\left(\mathrm{C}_{\mathrm{q}}\right), 74.6\left(\mathrm{C}_{\mathrm{q}}\right)$, 114.8 $(\mathrm{CH}), 115.2\left(\mathrm{C}_{\mathrm{q}}\right), 116.0(\mathrm{CH}), 116.3(\mathrm{CH}), 125.2(\mathrm{CH}), 125.3(\mathrm{CH}), 126.7(\mathrm{CH}), 128.4(2 \mathrm{CH}), 131.2(2 \mathrm{CH})$, $136.8\left(\mathrm{C}_{\mathrm{q}}\right), 136.9\left(\mathrm{C}_{\mathrm{q}}\right), 137.9(\mathrm{CH}), 138.3(\mathrm{CH}), 160.0\left(\mathrm{C}_{\mathrm{q}}\right), 163.2\left(\mathrm{C}_{\mathrm{q}}\right) ; \mathrm{MS}: \mathrm{m} / \mathrm{z}=389.2[\mathrm{M}+\mathrm{H}]^{+}$; HRMS: calcd. for $\mathrm{C}_{25} \mathrm{H}_{26} \mathrm{FN}_{2} \mathrm{O} 389.20237$, found 389.20155 (-2.102 ppm).

\subsubsection{1'-(4-fluorophenyl)-2-(naphthalen-2-yl)-1',4'-dihydrospiro[cyclohexane-1,5'- indazol]-2-ol}

2-bromo-naphtyl ( $0.69 \mathrm{~g}, 1$ eq.) was dissolved in a dry THF/toluene mixture $(1.7 \mathrm{ml} / 5 \mathrm{ml})$ before cooling to $78^{\circ} \mathrm{C}$. $n$-butyl lithium (soln. $1.6 \mathrm{M}$ in hexane, $2.5 \mathrm{ml}, 2.4$ eq.) was added at low temperature and the mixture was stirred for $1 \mathrm{~h}$. Subsequently, a solution of the ketone $10 \mathrm{~b}(0.5 \mathrm{~g}, 1.69 \mathrm{mmol}, 1 \mathrm{eq}$. $)$ in dry THF (9 ml) was added at low temperature, and the mixture was allowed to come back to $-30^{\circ} \mathrm{C}$ over $1 \mathrm{~h}$, under vigorously stirring. After complete consumption of the starting material, the reaction was quenched by addition of ammonium chloride (satd. soln., $50 \mathrm{ml})$, then the organics extracted with ethyl acetate $(3 \times 50 \mathrm{ml})$. By analogy with the previously conducted organometallic additions on the ketone precursor $\mathbf{1 0 b}$, the main diastereoisomer isolated by flashchromatography (PE/EtOAc 8/2) was assigned the (5S, 8S) stereochemistry.

$(5 S, \quad 8 S)-\quad$ l'-4-fluorophenyl)-2-(naphthalen-2-yl)-1',4'-dihydrospiro[cyclohexane-1,5'-indazol]-2-ol (13c): $\mathrm{C}_{28} \mathrm{H}_{25} \mathrm{FN}_{2} \mathrm{O}$; White solid; $\mathrm{Mp}=159-161^{\circ} \mathrm{C}$; Yield: $49 \%$; $\mathrm{M}=424.51 \mathrm{~g} / \mathrm{mol}$; IR (ZnSe) $v=3325,2936,1516$, $1225,839 \mathrm{~cm}^{-1} ;{ }^{1} \mathrm{H}$ NMR $(300 \mathrm{MHz}, \mathrm{CDCl} 3) \delta 1.65-1.99(\mathrm{~m}, 8 \mathrm{H}), 2.55(\mathrm{~d}, \mathrm{~J}=16.4 \mathrm{~Hz}, 1 \mathrm{H}), 2.66(\mathrm{td}, \mathrm{J}=13.5$ $\mathrm{Hz}, \mathrm{J}=4.2 \mathrm{~Hz}, 1 \mathrm{H}), 3.21(\mathrm{~d}, \mathrm{~J}=16.4 \mathrm{~Hz}, 1 \mathrm{H}), 6.23(\mathrm{~d}, \mathrm{~J}=10.3 \mathrm{~Hz}, 1 \mathrm{H}), 6.32(\mathrm{~d}, \mathrm{~J}=10.3 \mathrm{~Hz}, 1 \mathrm{H}), 6.91-7.00(\mathrm{~m}$, $3 \mathrm{H}), 7.18(\mathrm{~s}, 1 \mathrm{H}), 7.35-7.44(\mathrm{~m}, 2 \mathrm{H}), 7.59-7.77(\mathrm{~m}, 4 \mathrm{H}), 7.88(\mathrm{as}, 1 \mathrm{H}) ;{ }^{13} \mathrm{C}$ NMR $\left(75 \mathrm{MHz}, \mathrm{CDCl}_{3}\right) \delta 21.4$ $\left(\mathrm{CH}_{2}\right), 21.8\left(\mathrm{CH}_{2}\right), 27.8\left(\mathrm{CH}_{2}\right), 35.0\left(\mathrm{CH}_{2}\right), 35.8\left(\mathrm{CH}_{2}\right), 45.0\left(\mathrm{C}_{\mathrm{q}}\right), 77.0\left(\mathrm{C}_{\mathrm{q}}\right), 115.7(\mathrm{CH}), 116.0(\mathrm{CH}), 116.0(\mathrm{CH})$, $116.5\left(\mathrm{C}_{\mathrm{q}}\right), 125.1(\mathrm{CH}), 125.3(2 \mathrm{CH}), 125.6(\mathrm{CH}), 125.9(\mathrm{CH}), 125.9(\mathrm{CH}), 126.4(\mathrm{CH}), 127.4(\mathrm{CH}), 128.2(\mathrm{CH})$, $132.3\left(\mathrm{C}_{\mathrm{q}}\right), 132.4\left(\mathrm{C}_{\mathrm{q}}\right), 134.5(\mathrm{CH}), 135.6\left(\mathrm{C}_{\mathrm{q}}\right), 135.6\left(\mathrm{C}_{\mathrm{q}}\right), 137.8(\mathrm{CH}), 143.1\left(\mathrm{C}_{\mathrm{q}}\right), 159.8\left(\mathrm{C}_{\mathrm{q}}\right), 163.1\left(\mathrm{C}_{\mathrm{q}}\right)$; MS: $\mathrm{m} / \mathrm{z}=425.2[\mathrm{M}+\mathrm{H}]^{+}$;

\subsubsection{1-(4-fluorophenyl)-1'-(4-methoxyphenyl) spiro[4H-indazole-5,2'-cyclohexane]-1'-ol}

Under inert atmosphere, $\mathrm{PrMgCl}\left(2 \mathrm{M}\right.$ in THF, $0.84 \mathrm{ml}, 3.55 \mathrm{mmol}, 2.1$ eq.) was added at $-20^{\circ} \mathrm{C}$ to a solution of 4-iodo-anisole $(0.4 \mathrm{~g}, 1.69 \mathrm{mmol}, 1 \mathrm{eq}$. $)$ in dry THF $(10 \mathrm{ml})$. After $1 \mathrm{~h}$ of stirring at $-20^{\circ} \mathrm{C}$, a solution of ketone precursor $10 \mathrm{~b}(0.5 \mathrm{~g}, 1.69 \mathrm{mmol})$ in dry THF $(3 \mathrm{ml})$ was slowly added. The temperature was allowed to come back to room temperature and the mixture stirred overnight. The reaction was quenched by addition of sodium bicarbonate $(20 \%$ aq. soln., $50 \mathrm{ml})$, then extracted with ethyl acetate $(3 \times 50 \mathrm{ml})$. The combined organic layers were dried over magnesium sulfate, the solvent evaporated under reduced pressure and the crude purified by flash chromatography (cyclohexane / EtOAc 8/2) to deliver the addition product 13d. 
1-(4-fluorophenyl)-1'-(4-methoxyphenyl)spiro[4H-indazole-5,2'-cyclohexane]-1'-ol (13d): $\mathrm{C}_{25} \mathrm{H}_{25} \mathrm{FN}_{2} \mathrm{O}_{2}$; White solid; $\mathrm{Mp}=186-188^{\circ} \mathrm{C}$; Yield: $48 \%$; $\mathrm{M}=404.48 \mathrm{~g} / \mathrm{mol}$; IR $(\mathrm{ZnSe}) v=3368,2941,1517,1247,842 \mathrm{~cm}^{-1} ;{ }^{1} \mathrm{H}$ NMR $(300 \mathrm{MHz}, \mathrm{CDCl} 3) \delta 1.60-1.91(\mathrm{~m}, 7 \mathrm{H}), 2.45-2.54(\mathrm{~m}, 1 \mathrm{H}), 2.53(\mathrm{~d}, \mathrm{~J}=16.4 \mathrm{~Hz}, 1 \mathrm{H}), 3.10(\mathrm{~d}, \mathrm{~J}=16.3 \mathrm{~Hz}$, $1 \mathrm{H}), 3.70(\mathrm{~s}, 3 \mathrm{H}), 6.25(\mathrm{q}, \mathrm{J}=10.1 \mathrm{~Hz}, 2 \mathrm{H}), 6.71(\mathrm{~d}, \mathrm{~J}=9.0 \mathrm{~Hz}, 2 \mathrm{H}), 7.07-7.13(\mathrm{~m}, 2 \mathrm{H}), 7.24-7.30(\mathrm{~m}, 3 \mathrm{H}), 7.38$ $(\mathrm{d}, \mathrm{J}=9.0 \mathrm{~Hz}, 2 \mathrm{H}) ;{ }^{13} \mathrm{C} \mathrm{NMR}\left(75 \mathrm{MHz}, \mathrm{CDCl}_{3}\right) \delta 21.5\left(\mathrm{CH}_{2}\right), 21.8\left(\mathrm{CH}_{2}\right), 27.7\left(\mathrm{CH}_{2}\right), 34.9\left(\mathrm{CH}_{2}\right), 35.9\left(\mathrm{CH}_{2}\right)$, $44.9\left(\mathrm{CH}_{2}\right), 55.3\left(\mathrm{CH}_{3}\right), 76.6\left(\mathrm{C}_{\mathrm{q}}\right), 112.5(2 \mathrm{CH}), 115.8(\mathrm{CH}), 115.9(\mathrm{CH}), 116.2(\mathrm{CH}), 116.6\left(\mathrm{C}_{\mathrm{q}}\right), 125.1(\mathrm{CH})$, $125.2(\mathrm{CH}), 127.9(2 \mathrm{CH}), 135.1(\mathrm{CH}), 135.9\left(\mathrm{C}_{\mathrm{q}}\right), 138.0\left(\mathrm{C}_{\mathrm{q}}\right), 138.1(\mathrm{CH}), 158.4\left(\mathrm{C}_{\mathrm{q}}\right), 159.9\left(\mathrm{C}_{\mathrm{q}}\right), 163.2\left(\mathrm{C}_{\mathrm{q}}\right)$; HRMS: calcd. for $\mathrm{C}_{25} \mathrm{H}_{26} \mathrm{O}_{2} \mathrm{~N}_{2} \mathrm{~F} 405.19728$, found 405.19811 (2.042 ppm).

\subsubsection{1-(4-fluorophenyl)-1,6-dihydrocyclohepta-5,6-cyclohexyl[c]pyrazole (16)}

A mixture of alcohols 11 and $12(0.1 \mathrm{~g}, 0.335 \mathrm{mmol}, 1 \mathrm{eq}$.) obtained by addition of DIBAL-H to the ketone $10 \mathrm{~b}$ (vide supra) was treated with the Burgess reagent $(0.176 \mathrm{~g}, 0.74 \mathrm{mmol}, 2.2 \mathrm{eq}$.) in dry THF (20 ml). The mixture was refluxed under nitrogen atmosphere for $1 \mathrm{~h}$, then, after complete consumption of the starting material, the solvent was evaporated. The crude product was purified by flash chromatography (PE / EtOAc 95/5) to conduct to the rearrangement product 16. $\mathrm{C}_{18} \mathrm{H}_{17} \mathrm{FN}_{2}$; White solid; m.p. $77-79^{\circ} \mathrm{C}$; Yield: $87 \%$; $\mathrm{M}=280.34 \mathrm{~g} / \mathrm{mol}$; IR $(\mathrm{ZnSe}) v=2933,1514,1397,1229,981,842 \mathrm{~cm}^{-1}$; ${ }^{1} \mathrm{H}$ NMR $(300 \mathrm{MHz}, \mathrm{CDCl} 3) \delta 1.61-2.00(\mathrm{~m}, 6 \mathrm{H}), 2.30-$ $2.44(\mathrm{~m}, 3 \mathrm{H}), 5.43\left(\mathrm{dd}, \mathrm{J}_{1}=9.8 \mathrm{~Hz}, \mathrm{~J}_{2}=6.0 \mathrm{~Hz}, 1 \mathrm{H}\right), 6.37-6.41(\mathrm{~m}, 2 \mathrm{H}), 7.12-7.18(\mathrm{~m}, 2 \mathrm{H}), 7.53-7.57(\mathrm{~m}, 2 \mathrm{H})$, $7.69(\mathrm{~s}, 1 \mathrm{H}) ;{ }^{13} \mathrm{C}$ NMR $\left(75 \mathrm{MHz}, \mathrm{CDCl}_{3}\right) \delta 21.5\left(\mathrm{CH}_{2}\right), 24.2\left(\mathrm{CH}_{2}\right), 28.6\left(\mathrm{CH}_{2}\right), 30.6\left(\mathrm{CH}_{2}\right), 38.8(\mathrm{CH}), 113.9$ $(\mathrm{CH}), 115.8(\mathrm{CH}), 115.9(\mathrm{CH}), 116.2(\mathrm{CH}), 122.4\left(\mathrm{C}_{\mathrm{q}}\right), 125.3(\mathrm{CH}), 125.4(\mathrm{CH}), 129.7(\mathrm{CH}), 135.4\left(\mathrm{C}_{\mathrm{q}}\right), 138.3$ $\left(\mathrm{C}_{\mathrm{q}}\right), 139.2(\mathrm{CH}), 159.9\left(\mathrm{C}_{\mathrm{q}}\right), 163.2\left(\mathrm{C}_{\mathrm{q}}\right)$; MS m/z = 281.1 [M+H] $]^{+}$; HRMS: calcd. for $\mathrm{C}_{18} \mathrm{H}_{18} \mathrm{FN}_{2} 281.14573$, found $281.14619(4.754 \mathrm{ppm})$.

\subsubsection{1'-(4-fluorophenyl)-1',4',6',7'-tetrahydrospiro[cyclohexane-1,5'-indazol]-2-ol (17)}

A crude mixture of alcohols 11 and $12(0.15 \mathrm{~g}, 0.5 \mathrm{mmol}, 1$ eq.) was dissolved in ethanol $(5 \mathrm{ml}) . \mathrm{Pd} / \mathrm{C}(0.015$ g) was added and hydrogen gas was bubbled for $10 \mathrm{~min}$ in the reaction mixture. Aqueous hydrogen chloride (1 M soln, $0.5 \mathrm{ml}, 0.5 \mathrm{mmol}, 1$ eq.) was added to the solution, and the reaction was stirred under hydrogen atmosphere overnight. The mixture was filtered on a celite pad and the solvent was evaporated. Subsequently the residue was dissolved in DCM $(20 \mathrm{ml})$ and washed with sodium bicarbonate $(20 \mathrm{ml})$. The organic materials were further extracted from the aqueous layer with DCM $(2 \times 20 \mathrm{ml})$, and the combined organic layers were dried over magnesium sulfate and evaporated to conduct to a crude product which was subsequently used without further purification. $\mathrm{C}_{18} \mathrm{H}_{21} \mathrm{FN}_{2} \mathrm{O}$; White solid; m.p. $179-180^{\circ} \mathrm{C}$; Yield: $60 \% ; \mathrm{M}=300.16 \mathrm{~g} / \mathrm{mol}$; IR (ZnSe) $v=3324$, 2933, 1514, 1222, 1057, $838 \mathrm{~cm}^{-1} ;{ }^{1} \mathrm{H}$ NMR $\left(300 \mathrm{MHz}, \mathrm{CDCl}_{3}\right) \delta 1.39-2.10(\mathrm{~m}, 9 \mathrm{H}), 2.29(\mathrm{~d}, \mathrm{~J}=15.6 \mathrm{~Hz}, 1 \mathrm{H})$, 2.51-2.84 (m, 4H), 3.50-3.62 (m, 1H), $7.13(\mathrm{t}, \mathrm{J}=8.6 \mathrm{~Hz}, 2 \mathrm{H}), 7.45-7.51(\mathrm{~m}, 3 \mathrm{H}) ;{ }^{13} \mathrm{C} \mathrm{NMR}\left(75 \mathrm{MHz}, \mathrm{CDCl}_{3}\right) \delta$ 19.6,19.7 $\left(\mathrm{CH}_{2}\right), 21.1,21.1\left(\mathrm{CH}_{2}\right), 22.7,23.5\left(\mathrm{CH}_{2}\right), 30.2,30.2\left(\mathrm{CH}_{2}\right), 30.4,30.5\left(\mathrm{CH}_{2}\right), 31.5,32.4\left(\mathrm{CH}_{2}\right), 37.5$, $37.5\left(\mathrm{CH}_{2}\right), 74.1,76.2(\mathrm{CH}), 116.0,116.3(2 \mathrm{CH}), 117.0,117.2\left(2 \mathrm{C}_{\mathrm{q}}\right), 124.8,124.8(\mathrm{CH}), 124.9,124.9(\mathrm{CH})$, $137.5,137.8\left(2 \mathrm{C}_{\mathrm{q}}\right), 139.0,139.3(\mathrm{CH}), 159.8,163.1\left(2 \mathrm{C}_{\mathrm{q}}\right) ; \mathrm{MS} \mathrm{m} / \mathrm{z}=301.3[\mathrm{M}+\mathrm{H}]^{+}$.

\subsubsection{1. methyl\{[(1'-(4-fluorophenyl)-1',4',6',7'-tetrahydrospiro[cyclohexane-1,5'-indazol]-2-} yl)oxy] sulfonyl\}- carbamate (18)

Burgess reagent $(0.04 \mathrm{~g}, 0.159 \mathrm{mmol}, 2.2 \mathrm{eq}$.) was added to a solution of alcohol 17 (0.04 g, $0.133 \mathrm{mmol}, 1$ eq.) in dry THF $(8 \mathrm{ml})$. The mixture was refluxed under nitrogen atmosphere for $1 \mathrm{~h}$, then, after complete consumption of the starting material, the solvent was evaporated. The crude product was purified by flash chromatography (DCM / MeOH 9/1) to conduct to the sulfonamide 18. $\mathrm{C}_{20} \mathrm{H}_{24} \mathrm{FN}_{3} \mathrm{O}_{5} \mathrm{~S}$; White solid; m.p. $105^{\circ} \mathrm{C}$; Yield: $26 \% ; \mathrm{M}=437.5 \mathrm{~g} / \mathrm{mol}$; IR $(\mathrm{ZnSe}) v=2937,1758,1517,1236,1174,900 \mathrm{~cm}^{-1} ;{ }^{1} \mathrm{H}$ NMR $(300 \mathrm{MHz}$, $\mathrm{CDCl} 3) \delta 1.47-1.99(\mathrm{~m}, 10 \mathrm{H}), 2.39-2.86(\mathrm{~m}, 5 \mathrm{H}), 3.73-3.75(\mathrm{~m}, 3 \mathrm{H}), 4.70(\mathrm{ls}, 1 \mathrm{H}) ; 7.12(\mathrm{t}, \mathrm{J}=8.6 \mathrm{~Hz}, 1 \mathrm{H}), 7.42-$ $7.47(\mathrm{~m}, 3 \mathrm{H}) ;{ }^{13} \mathrm{C}$ NMR $\left(75 \mathrm{MHz}, \mathrm{CDCl}_{3}\right) \delta 19.1,19.3\left(\mathrm{CH}_{2}\right), 20.5\left(\mathrm{CH}_{2}\right), 27.0,27.4\left(\mathrm{CH}_{2}\right), 29.5,30.2\left(\mathrm{CH}_{2}\right)$, 31.0, 31.2 $\left(\mathrm{CH}_{2}\right), 37.4,37.6\left(\mathrm{CH}_{2}\right), 54.0\left(\mathrm{CH}_{3}\right), 115.7,115.9\left(\mathrm{C}_{\mathrm{q}}\right), 116.1,116.3(2 \mathrm{CH}), 124.9,125.0(2 \mathrm{CH}), 136.2$, $136.2\left(\mathrm{C}_{\mathrm{q}}\right), 136.7,137.3\left(\mathrm{C}_{\mathrm{q}}\right), 139.1,139.4(\mathrm{CH}), 159.8,163.1\left(\mathrm{C}_{\mathrm{q}}\right) ; \mathrm{MS} \mathrm{m} / \mathrm{z}=438.1[\mathrm{M}+\mathrm{H}]^{+}$.

\subsubsection{2. $N$-[(E)-[1-(4-fluorophenyl)spiro[4H-indazole-5,2'-cyclohexane]-1'-ylidene]amino]-4- methyl-benzenesulfonamide (19)}

A solution of the ketone $10 \mathrm{~b}(0.5 \mathrm{~g}, 1.69 \mathrm{mmol}, 1 \mathrm{eq}$.$) in ethanol (3 \mathrm{ml})$ was added to a solution of ptosylhydrazide $(0.38 \mathrm{~g}, 0.02 \mathrm{mmol}, 1.2 \mathrm{mmol})$ in ethanol $(10 \mathrm{ml})$. Subsequently, a few drops of concentrated hydrochloric acid were added, and the mixture was vigorously stirred overnight at room temperature. The white precipitate was filtered and further washed with n-pentane to conduct to a white powder subsequently used without further purification. $\mathrm{C}_{25} \mathrm{H}_{25} \mathrm{FN}_{4} \mathrm{O}_{2} \mathrm{~S}$; White solid; $\mathrm{Mp}=183-185^{\circ} \mathrm{C}$; Yield: $77 \%$; $\mathrm{M}=464.56 \mathrm{~g} / \mathrm{mol}$; IR $(\mathrm{ZnSe}) v=3214,2941,1514,1335,1167 \mathrm{~cm}^{-1} ;{ }^{1} \mathrm{H}$ NMR $\left(300 \mathrm{MHz}, \mathrm{CDCl}_{3}\right) \delta 1.70-1.73(\mathrm{~m}, 6 \mathrm{H}), 2.28(\mathrm{~s}, 3 \mathrm{H})$, 2.23 (as, 2H), $2.75(\mathrm{~d}, \mathrm{~J}=16.0 \mathrm{~Hz}, 1 \mathrm{H}), 3.10(\mathrm{~d}, \mathrm{~J}=16.0 \mathrm{~Hz}, 1 \mathrm{H}), 6.10(\mathrm{~d}, \mathrm{~J}=10.1 \mathrm{~Hz}, 1 \mathrm{H}), 6.42(\mathrm{~d}, \mathrm{~J}=10.1 \mathrm{~Hz}$, 
$1 \mathrm{H}), 7.15-7.20(\mathrm{~m}, 4 \mathrm{H}), 7.39-7.48(\mathrm{~m}, 3 \mathrm{H}), 7.70(\mathrm{~d}, \mathrm{~J}=8.3 \mathrm{~Hz}, 2 \mathrm{H}),{ }^{13} \mathrm{C} \mathrm{NMR}\left(75 \mathrm{MHz}, \mathrm{CDCl}_{3}\right) \delta 21.0\left(\mathrm{CH}_{2}\right)$, 21.6 $\left(\mathrm{CH}_{3}\right), 23.5\left(\mathrm{CH}_{2}\right), 25.9\left(\mathrm{CH}_{2}\right), 29.2\left(\mathrm{CH}_{2}\right), 37.1\left(\mathrm{CH}_{2}\right), 45.1\left(\mathrm{CH}_{2}\right), 115.1(\mathrm{CH}), 115.8\left(\mathrm{C}_{\mathrm{q}}\right), 116.1(\mathrm{CH})$, $116.4(\mathrm{CH}), 125.0(\mathrm{CH}), 125.1(\mathrm{CH}), 127.9(2 \mathrm{CH}), 129.5(2 \mathrm{CH}), 134.7(\mathrm{CH}), 135.3\left(\mathrm{C}_{\mathrm{q}}\right), 136.2\left(\mathrm{C}_{\mathrm{q}}\right), 138.1(\mathrm{CH})$, $143.9\left(\mathrm{C}_{\mathrm{q}}\right), 160.0\left(\mathrm{C}_{\mathrm{q}}\right), 163.2\left(\mathrm{C}_{\mathrm{q}}\right), 163.2\left(\mathrm{C}_{\mathrm{q}}\right)$; HRMS: calcd. for $\mathrm{C}_{25} \mathrm{H}_{26} \mathrm{FN}_{4} \mathrm{O}_{2} \mathrm{~S} 465.175501$, found 465.17683 (2.86 ppm).

\subsubsection{1-(4-fluorophenyl)spiro[4H-indazole-5,3'-cyclohexene] (15)}

Under inert atmosphere, $n$-BuLi $(0.55 \mathrm{ml}, 0.81 \mathrm{mmol}, 2.5$ eq. $)$ was slowly added over $15 \mathrm{~min}$ to a solution of the tosylhydrazone 25 ( $0.15 \mathrm{~g}, 0.32 \mathrm{mmol}, 1 \mathrm{eq}$.) in dry THF $(3 \mathrm{ml})$. The mixture was allowed to come back to room temperature over $3 \mathrm{~h}$, and then quenched with water $(20 \mathrm{ml})$ before extracting the organic materials with EtOAc ( $3 \times 20 \mathrm{ml})$. Flash chromatography (PE/EtOAc 95/5) of the obtained crude material conducted to the desired elimination product 15. $\mathrm{C}_{18} \mathrm{H}_{17} \mathrm{FN}_{2}$; Light yellow solid; $\mathrm{Mp}=118-120^{\circ} \mathrm{C}$; Yield: $34 \% ; \mathrm{M}=280.34 \mathrm{~g} /$ mol; IR (ZnSe) $v=2930,1667,1609,1514 \mathrm{~cm}^{-1}$; ${ }^{1} \mathrm{H}$ NMR $(300 \mathrm{MHz}, \mathrm{CDCl} 3) \delta 1.63-1.70$ (m, 4H), $2.02(1 \mathrm{~s}$, 2H), $2.70(\mathrm{~d}, \mathrm{~J}=2.0 \mathrm{~Hz}, 2 \mathrm{H}), 5.63-5.69(\mathrm{~m}, 2 \mathrm{H}), 5.81(\mathrm{~d}, \mathrm{~J}=9.9 \mathrm{~Hz}, 1 \mathrm{H}), 6.36(\mathrm{~d}, \mathrm{~J}=9.9 \mathrm{~Hz}, 1 \mathrm{H}), 7.15(\mathrm{t}, \mathrm{J}=8.6$ $\mathrm{Hz}, 2 \mathrm{H}), 7.41-7.48(\mathrm{~m}, 3 \mathrm{H}) ;{ }^{13} \mathrm{C}$ NMR $(75 \mathrm{MHz}, \mathrm{CDCl} 3) \delta 18.7\left(\mathrm{CH}_{2}\right), 25.2\left(\mathrm{CH}_{2}\right), 32.5\left(\mathrm{CH}_{2}\right), 33.9\left(\mathrm{CH}_{2}\right), 37.5$ $\left(\mathrm{C}_{\mathrm{q}}\right), 113.8(\mathrm{CH}), 115.4\left(\mathrm{C}_{\mathrm{q}}\right), 116.0(\mathrm{CH}), 116.3(\mathrm{CH}), 125.2(\mathrm{CH}), 125.3(\mathrm{CH}), 127.3(\mathrm{CH}), 132.2(\mathrm{CH}), 138.4$ $(\mathrm{CH}), 139.3(\mathrm{CH}), 160.0\left(\mathrm{C}_{\mathrm{q}}\right), 163.3\left(\mathrm{C}_{\mathrm{q}}\right) ; \mathrm{MS} \mathrm{m} / \mathrm{z}=281.2[\mathrm{M}+\mathrm{H}]^{+}$; HRMS: calcd. for $\mathrm{C}_{18} \mathrm{H}_{18} \mathrm{FN}_{2} 281.14485$, found $281.14570(3.011 \mathrm{ppm})$.

\section{References}

1. O. Schakman, S. Kalista, C. Barbé, A. Loumaye, J. P. Thissen, Int. J. Biochem. Cell Biol. 2013, 45, $2163-$ 2172.

2. a) R. S. Weinstein, $N$ Engl J Med 2011, 365, 62-70; b) E. Canalis, G. Mazziotti, A. Giustina, J. P. Bilezikian, Osteoporos Int 2007, 18, 1319-1328.

3. D. H. van Raalte, D. M. Ouwens, M. Diamant, Eur. J. Clin. Invest. 2009, 39, 81-93.

4. J. E. Goodwin, D. S. Geller, Pediatric Nephrology 2011, 27, 1059-1066.

5. A. Ali, C. F. Thompson, J. M. Balkovec, D. W. Graham, M. L. Hammond, N. Quraishi, J. R. Tata, M. Einstein, L. Ge, G. Harris, T. M. Kelly, P. Mazur, S. Pandit, J. Santoro, A. Sitlani, C. Wang, J. Williamson, D. K. Miller, C. M. Thompson, D. M. Zaller, M. J. Forrest, E. Carballo-Jane, S. Luell, J. Med. Chem. 2004, 47, 2441-2452.

6. C. J. Bungard, G. D. Hartman, J. J. Manikowski, J. J. Perkins, C. Bai, P. E. Brandish, D. H. Euler, J. C. Hershey, A. Schmidt, Y. Fang, R. T. Norcross, T. H. Rushmore, C. D. Thompson, R. S. Meissner, Bioorg. Med. Chem. 2011, 19, 7374-7386.

7. P. E. Eaton, P. G. Jobe, Synthesis 1983, 796-797.

8. J. Siewert, A. Textor, S. Grond, P. von Zezschwitz, Chem. Eur. J. 2007, 13, 7424-7431.

9. a) J. A. Elings, H. E. B. Lempers, R. A. Sheldon, Eur. J. Org. Chem. 2000, 1905-1911; b) A. Cook, I. Gunawardana, M. Huestis, K. W. Hunt, N. C. Kallan, A. T. Metcalf, B. Newhouse, M. Siu, T. P. Tang, A. Thomas, M. Volgraf in Heterocyclic inhibitors of beta-secretase for the treatement of neurogenerative diseases, WO/2012/071458 Eds.: Array Biopharma Inc and Genentech.

10. a) A. de Groot, B. J. M. Jansen, Tetrahedron Lett. 1976, 17, 2709-2710; b) B. J. M. Jansen, C. C. J. Hendrikx, N. Masalov, G. A. Stork, T. M. Meulemans, F. Z. Macaev, A. de Groot, Tetrahedron 2000, 56, 2075-2094.

11.D. D. Holsworth, Burgess dehydrating reagent, Name Reactions for Functional Group Transformations 2007, 189-206.

12. O.A. McNamara, A.R. Maguire, Tetrahedron 2011, 67, 9-40 